\title{
Die betroubaarheid van die Nuwe Testament vanuit 'n tekskritiese oogpunt
}

\author{
JH Petzer
}

\begin{abstract}
The reliability of the New Testament from a text-critical point of view

In this article the present and past state of the text of the Greek New Testament is subjected to evaluation, with the purpose of determining the reliability of the text for exegesis and translation. The subject is approached historically and centers around the discussion of the Textus Receptus, the text of Westcott and Hort and the latest editions of The Greek New Testament by the United Bible Societies, together with the 26th edition of the Nestle-Aland series of texts. A judgement is also made as to possible alternatives for the above-mentioned texts and the claims of other methodological groups are put to the test. A final conclusion as to the reliability of the text is followed by an attempt to discuss the consequences of the conclusions for the general use of the Greek New Testament.
\end{abstract}

Die vraag na die betroubaarheid van die teks van die Griekse Nuwe Testament is geen nuwe vraag nie. Dit bestaan waarskynlik so lank as die teks (of tekste) self. Reeds vanaf die vroegste tye van oorlewering is hierdie vraag deur skriptors, eksegete en vertalers gevra. Elke skriptor wat ' $n$ bewustelike verandering in sy manuskrip gemaak het en so die teks probeer verbeter het, is waarskynlik met hierdie vraag gekonfronteer. Baie min het immers veranderinge in die manuskripte aangebring met die doel om die teks te vervals. Ook kerkvaders was bewus van die probleem. Dit is bekend dat veral Origenes en Hieronymus, maar ook enkele ander kerkvaders, soms aanmerkings ten opsigte van variante lesings wat aan hulle bekend is, gemaak het (vgl Metzger 1968a: 151-155; 1968b: $88-103 ; 1975$ : 340-349; 1980: 189-210). Vir vroeë

- Hierdie artikel is ' $n$ verwerking van die eerste hoofstuk van ' $n$ proefskrif met die titel Nuwe-Testamentiese Tekskritiek sedert 1881 - 'n Kritiese evaluering van die belangrikste metoderigtings, met besondere verwysing na die laaste gedeelte van die twintigste eeu, wat in 1987 by die Potchefstroomse Universiteit vir Christelike Hoër Onderwys vir die graad $\mathrm{D}$ Litt ingedien is. Die studie is met finansiële ondersteuning van die RGN onderneem. 
vertalers was dit uiteraard ' $n$ probleem. Die groot aantal verskille onder die oud-Latynse manuskripte was een van die redes waarom die Vulgaat, 'n standaarduitgawe van die Latynse teks, sy beslag gekry het (vgl Metzger 1968a: 76).

Hoewel die betroubaarheid van die teks van die Nuwe Testament dus lank voor die uitvinding van die boekdrukkuns 'n erkende probleem was, was dit egter nie ' $n$ strydpunt nie. Eers sedert die publikasie van Erasmus se teks in 1516, en veral sedert die publikasie van die Textus Receptus (TR) in die daaropvolgende eeu, het dit 'n strydpunt geword. Uiteindelik het dit gelei tot die publikasie van verskillende tekste met verskillende kenmerke, wat elk op bepaalde gronde op betroubaarheid aanspraak gemaak het. Deur die loop van die laaste vier-en-'n-half eeue sedert die publikasie van die eerste Griekse Nuwe Testament, is letterlik honderde tekste gepubliseer, waarvan elkeen deur ten minste sy samesteller as die mees betroubare aangebied is.

Onder hierdie omstandighede is dit natuurlik dat daar van tyd tot tyd vrae ten opsigte van die toestand van die teks gevra sal word en dat bepaal sal word hoe betroubaar die teks is en wat die konsekwensies daarvan vir ander dissiplines in die Nuwe-Testamentiese Wetenskap, soos die vertaling en verklaring van die Nuwe Testament, is. Veral die finale publikasie van die nuwe vertaling van die Bybel in Afrikaans in 1983 (NAB) en die kritiek waaraan dit tans onderworpe is, maak ' $n$ nuwe besinning oor die saak uiters relevant.

Die probleem word in hierdie artikel histories benader. Die belangrikste tekste wat sedert 1516 gepubliseer is, word aan die orde gestel om te bepaal hoe betroubaar hulle is en op watter gronde daar op betroubaarheid aanspraak gemaak word. Deur die onderwerp op hierdie wyse aan te pak, word nie alleen die relevante tekste met mekaar vergelyk ten einde elkeen se relatiewe betroubaarheid te beoordeel nie, maar word elke teks binne die historiese konteks waaruit dit voortgekom het, beoordeel. Dit spreek vanself dat slegs die mees relevante tekste bespreek word en dat die swaartepunt van die artikel by die toestand van kontemporêre tekste lê. Daarom word die meeste aandag aan die huidige toedrag van sake gewy en word die geskiedenis slegs oorsigtelik en vlugtig aan die orde gestel. Omdat die saak nie bloot teoretiese waarde het nie, maar vir die gebruik van die Nuwe Testament belangrik is, word gepoog om die saak so prakties moontlik voor te hou, deur te bepaal watter konsekwensies dit vir ander aspekte van die Nuwe-Testamentiese Wetenskap inhou.

Die geskiedenis van die teks van die Griekse Nuwe Testament kan in 
drie hooftydperke ingedeel word. Elke tydperk sentreer om ' $n$ bepaalde teks wat groot invloed uitgeoefen het vanweë besondere aansprake op betroubaarheid. Die eerste tydperk strek van die 15de tot 17 de eeu en sentreer om die TR. Die tweede strek van ongeveer die 18de tot vroeg-20ste eeu en sentreer om die kritiese teks van Westcott en Hort. Die derde tydperk strek vanaf die vroeë deel van die 20ste eeu en sentreer om die eklektiese teks, soos veral in die tekste van die Verenigde Bybelgenootskappe (UBS-reeks) (vgl Aland et al 1966; 1968; $1975 ; 1983$ ) en die 26ste uitgawe van die Nestle-Aland-reeks $\left(\mathrm{NA}^{26}\right)$ (vgl Aland et al 1979) na vore kom.

\section{DIE TEXTUS RECEPTUS (15de tot 17de eeu)}

Hoewel dit nie die eerste teks is wat gepubliseer is nie, was die TR die eerste teks wat daarin kon slaag om 'n oortuigende stempel van betroubaarheid te dra. Dit is die moeite werd om die geskiedenis van hierdie teks kortliks na te gaan (vgl o a Metzger 1968a: 95-106; Aland \& Aland 1982: 13-16; Jordaan 1975; Tarelli 1943: 155-162; Clark 1959: 749-756; Reicke 1966: 254-265; Bentley 1976: 33-53; De Jonge 1971; 1980: 381-389; 1984: 394-413 vir oorsig):

- Desiderius Erasmus publiseer die eerste Griekse Nuwe Testament in 1516. Oor hierdie teks is waarskynlik meer as oor die meeste ander vroeë uitgawes van die Griekse Nuwe Testament bekend. Dit is bekend dat die teks baie haastig en onnoukeurig saamgestel is. Ook is bepaal dat die teks op slegs twee laat-Bisantynse minuskels, een vir die Evangelies en een vir die res van die Nuwe Testament, berus. Vier ander manuskripte is vir kontroledoeleindes gebruik. Latere uitgawes is aan die hand van die Komplutensiese Poliglot, wat in 1522 verskyn het, gekorrigeer. Die 5de uitgawe van 1535 het uiteindelik die belangrikste geword, omdat dit as basis deur latere samestellers gebruik is.

- Onafhanklik van Erasmus word 'n teks van die Griekse Nuwe Testament, wat in 1522 as deel van die Komplutensiese Poliglot verskyn, saamgestel. Van hierdie teks is baie min bekend. Tog is bepaal dat dit effens meer wetenskaplik as Erasmus se teks saamgestel is. Dit is egter nie van veel groter waarde nie, omdat dit ook uitsluitlik op laat-Bisantynse manuskripte gebaseer is.

- Stephanus (Robert Estienne) publiseer in 1546 die eerste uitgawe van sy teks. Die teks was 'n samevoeging van Erasmus se teks en die 
Komplutensiese Poliglot, maar het veral op Erasmus se 5de uitgawe van 1535 berus.

- Theodore Beza publiseer in 1565 die eerste van tien uitgawes van die teks. Sy teks was weer ' $n$ blote weergawe van Stephanus se 4 de uitgawe met enkele veranderinge.

- Uiteindelik publiseer twee broers (of was hulle neefs?), Bonaventura en Abraham Elsevier, in 1624 'n sakuitgawe van die Griekse Nuwe Testament. Op sy beurt was hierdie teks weer ' $n$ samestelling van die teks van Beza en die 4de uitgawe van Stephanus. Ten einde die teks 'n groter bemarkingswaarde te gee, publiseer hulle in die voorwoord van die 2 de uitgawe van 1633 'n advertensie, waarin hulle beweer dat die teks deur almal aanvaar word en dat daar geen foute in voorkom nie: Textum ergo habes, nunc ab omnibus receptum: in quo nihil immutatum aut corruptum damus (aangehaal deur Metzger 1968a: 106). Hierdie woorde het die gewenste uitwerking gehad en waarskynlik die verwagtinge van die samestellers oortref, omdat hierdie teks vir eeue lank as die textus receptus aanvaar is en niemand durf waag het om daarvan af te wyk nie.

Op hierdie wyse het die TR geweldige invloed verkry, soveel so dat dit die Nuwe-Testamentiese Tekskritiek heeltemal gedomineer het en 'n metodologiese stagnasie in hierdie wetenskap veroorsaak het. Dit is as grondteks vir baie Bybelvertalings gebruik. In feitlik elke taal waarin die Bybel vertaal is, is die 'moedervertaling' op die TR gebaseer. Die King James Version (KJV) of Authorized Version (AV) van 1611 in Engeland en die Statevertaling (SV) in Nederland is twee bekende voorbeelde. Selfs die ou Afrikaanse vertaling van 1933 (OAB) is op die TR gebaseer, ondanks die feit dat beter kritiese uitgawes van die Griekse Nuwe Testament op daardie stadium beskikbaar was.

Hoe betroubaar is die TR? Vandag bestaan daaroor weinig twyfel meer dat die TR ' $n$ swak teks is en nie as 'n betroubare weergawe van die outograwe geag kan word nie. Veral vier redes kan daarvoor aangebied word:

- Die gronde waarop die teks op betroubaarheid aanspraak maak, is misleidend en irrelevant. Dit berus op 'n blote advertensie om die teks te bemark en sê in werklikheid niks oor die aard, inhoud en ouderdom van die teks nie.

- Op teksteoretiese gronde is die TR onbetroubaar. Sedert die publikasie van die editiones principes blyk dit dat tekste saamgestel is met weinig aandag aan die presiese bewoording van die teks. Vir die 
samestellers was dit skynbaar voldoende as hulle teks met die aanvaarde inhoud van die aanvaarde of bekende Nuwe Testament van die tyd (die teks van die Vulgata) ooreengekom het. Of dit met die presiese bewoording van die outograwe ooreengestem het, was van minder belang.

- Ook op metodologiese gronde is die teks onbetroubaar. Die oerbronne van die teks, die tekste van Erasmus en die Komplutensiese Poliglot, is onwetenskaplik saamgestel. Die toestand vererger ten opsigte van die latere bronne, die tekste van Stephanus en Beza, aangesien laasgenoemde tekste selfs minder op manuskripte gebaseer is as die tekste van Erasmus en die Poliglot, maar bloot op die ouer gepubliseerde uitgawes gebaseer is. Op hierdie wyse het, byvoorbeeld, die tekskrities korrupte comma Iohanneum, die verwysing na die sogenaamde 'drie hemelse Getuies' (1 Joh 5: 7-8), sy weg tot in die TR en die meeste Bybelvertalings gevind, ondanks die feit dat hierdie teks slegs in manuskripte van die laat-Middeleeue en enkele vertalings gevind word. Dit spreek vanself dat ' $n$ teks, wat nie op grond van ' $n$ beoordeling van die waarde van die beskikbare primêre bronne gebaseer is nie, vandag nie op betroubaarheid aanspraak kan maak nie.

- Laastens is die TR ook op materiële gronde nie aanvaarbaar nie, omdat dit uitsluitlik op laat-Bisantynse manuskripte, wat later as swak en onbetroubare manuskripte bewys is, gebaseer is (vgl Jordaan 1975: 64-70). Dit is die toedrag van sake ten spyte daarvan dat Erasmus kodeks 1, 'n Caesareaanse manuskrip van groter waarde as sy twee primêre manuskripte, slegs vir kontroledoeleindes gebruik het; dat die samesteller van die Griekse Nuwe Testament in die Komplutensiese Poliglot, wat volgens sy eie erkenning die manuskripte in die Vatikaan se Biblioteek as bron gebruik het, kodeks Vatikanus (B), tot sy beskikking gehad het; en dat Beza kodeks Bezae (D) tot sy beskikking gehad het.

Hoewel 'n mens nie te kras wil oordeel nie, in die lig daarvan dat die tekssamestellers van die tyd nie die metodologiese kennis wat vandag beskikbaar is en op grond waarvan manuskripte se waarde bepaal word, gehad het nie, kan hierdie gebrek aan kennis nie vandag meer gebruik word om die TR te verdedig nie en moet die TR, soos ook die vertalings wat daarop gegrond is, as ' $n$ swak en onbetroubare weergawe van die oorspronklike geskrifte verwerp word. Die vertalers van die NAB was dus korrek om nie die TR as grondteks te gebruik nie. 
Hierdeur het hulle in die voetspoor van ander moderne vertalings gevolg deur 'n kritiese uitgawe van die Griekse teks as grondteks te gebruik. Weer eens wil 'n mens egter nie te kras oor die keuse van die TR as grondteks van die $O A B$ oordeel nie. Uit geskrifte van die tyd blyk dat daar eiesoortige probleme was wat die vertalers laat oordeel het dat 'n kritiese teks van die Nuwe Testament die hele vertaalpoging sou laat skipbreuk ly (vgl Petzer 1985: 78-80) - iets wat op die lang duur meer skade sou berokken het as wat die gebruik van die TR uiteindelik berokken het. Tog sou die huidige vertalers vandag heelwat ongegronde kritiek gespaar gebly het, indien die korrekte keuse in 1933 reeds gemaak was.

\section{DIE TEXTUS CRITICUS (18de eeu tot middel 20ste eeu)}

\subsection{Van Mill tot Tischendorf (1707-1881)}

Nieteenstaande die onbetroubaarheid van die TR, het die TR die tekskritiese toneel vir bykans twee-en-'n-halwe eeu sodanig gedomineer, dat daar tot laat in die 19de eeu gewag moes word, voordat die resultate van die wetenskaplike bestudering van die manuskripte en die metodologiese ontwikkelinge van die $18 \mathrm{de}$ en $19 \mathrm{de}$ eeu praktiese neerslag gevind het en die rigting waarin die Nuwe-Testamentiese Tekskritiek beweeg het, betekenisvol verander het. Die stryd om 'n meer betroubare kritiese teks het reeds vroeg in die $18 \mathrm{de}$ eeu, kort na die publikasie van Mill se teks in 1707 begin. Die koersverandering het egter eers in 1881 met die publikasie van Westcott en Hort se teks werklikheid geword. Eers toe het die krities-wetenskaplike teks die TR vervang. In hierdie stryd om die vestiging van die kritiese teks het verskillende tekskritici egter 'n belangrike rol in die ontwikkeling van die metodiek gespeel, waarsonder die deurbraak in 1881 nie moontlik sou gewees het nie (vgl Metzger 1968a: 106-129; Aland \& Aland 1982: 17-24; Epp 1976: 217-234; Bristol 1950: 101-112).

- John Mill vestig die aandag op die bewoording en die geweldige variasie wat in die bewoording van die manuskripte voorkom deur die publikasie van 'n teks in 1707, wat hy van 'n kritiese apparaat met 30000 variante lesings voorsien. Hierdie teks het 'n belangrike verandering ten opsigte van die teksteoretiese uitgangspunte waarmee die teks benader is, ingelei, wat vir die metodologiese ontwikkeling van die Nuwe-Testamentiese Tekskritiek baie belangrik is. 
- Johann Albrecht Bengel begin die samestelling van die teks metodologies of dan krities-wetenskaplik benader, deurdat hy na aanleiding van die variasie-eenhede in Mill se teks die manuskripte begin bestudeer, dit uiteindelik in twee groepe verdeel en in 'n publikasie in 1725 kriteria voorstel aan die hand waarvan daar tussen variante lesings gekies moet word. So ontstaan 'n metodologiese benadering tot die samestelling van die teks.

- Johann Salomo Semler verfyn Bengel se groepering van manuskripte in die middel van die 18de eeu deur drie groepe te identifiseer. Deur hierdie groepe as resensies te tipeer, stel Semler die beginsel van die rekonstruksie van die geskiedenis van die teks daar.

- Johann Jakob Griesbach verfyn weer Semler se metodiek laat in die $18 \mathrm{de}$ eeu, deur 'n genealogiese verband tussen die Bisantynse en ander twee groepe te identifiseer. Hierdeur maak hy 'n belangrike waarneming ten opsigte van die aard van die geskiedenis van die teks.

- Karl Lachmann bied in 1831 die teoretiese onderbou vir die groepering van manuskripte en die keuse van een groep bo die ander deur sy teorie van die genealogie van manuskripte. Hiermee word die ruimte vir die uiteindelike formulering en ontwikkeling van die klassieke metode geskep, deurdat die belangrike tekskritiese beginsel dat manuskripte geweeg en nie getel moet word nie, metodologies gemotiveer word.

- Constantin von Tischendorf vestig die aandag op die belang van die ouer manuskripte deur sy ontdekking en beskikbaarstelling van die lesings van talle manuskripte, waaronder kodeks Sinaiticus (Alef), in die uitgebreide kritiese apparaat in die 8ste uitgawe van sy teks, wat in 1869 tot 1872 gepubliseer word. Deur sy ontdekking en beklemtoning van Alef stel hy saam met $B$ die belangrikste bron vir die herstel van die teks tot op daardie stadium beskikbaar.

\subsection{Westcott en Hort (1881)}

Bogenoemde ontwikkelinge het die weg voorberei vir die belangrike koersverandering in die Nuwe-Testamentiese Tekskritiek wat deur Westcott en Hort meegebring is, 'n koersverandering wat praktiese vergestalting gevind het in die verwerping van die $T R$ en die vestiging van die krities-wetenskaplike metode en teks deur Brooke Foss Westcott en Fenton John Anthony Hort. 'n Ontleding van hulle Introduction (Westcott \& Hort 1974), wat hulle teks, wat in 1881 verskyn het, vergesel 
het en waarin hulle die verwerping van die $T R$ en die aansprake op betroubaarheid van hul eie teks sistematies en beredeneerd motiveer, toon waarom juis hulle, en nie een van hulle voorgangers nie, hierdie koersverandering kon meebring. Dit is naamlik veral geleë in hulle rekonstruksie van die geskiedenis van die teks, wat die kern vorm van beide hulle verwerping van die TR en die samestelling van hulle eie teks (vgl Metzger 1968a: 129-135; Aland \& Aland 1982: 24-29; Epp 1976: 237-238 vir goeie opsommings; ook Westcott en Hort 1974: 73-282).

In aansluiting by hulle voorgangers identifiseer Westcott en Hort drie lokale tekstipes onder die manuskripte van die Griekse Nuwe Testament, naamlik die Alexandrynse, Westerse en Siriese tekstipes. Hulle verwerping van die $T R$ het hulle op die onderlinge verhouding van hierdie drie tekstipes gebaseer. Hulle het naamlik oortuigend aangetoon dat die Siriese teks ' $n$ sekondêre posisie in die geskiedenis van die teks inneem, omdat dit genealogies aan beide die Alexandrynse en Westerse verwant is. Deur aan te toon dat (a) die Siriese teks nie in die patristiese geskrifte voor Chrysostomos voorkom nie; (b) daar lang lesings in die Siriese teks voorkom waarvan 'n gedeelte in die Alexandrynse teks en 'n gedeelte in die Westerse teks gevind word (die sogenaamde gevalle van samevoeging of konflasie); en (c) die Siriese teks op grond van die interne getuienis van sy lesings van 'n swakker gehalte as die lesings in die ander tekstipes is, het hulle bewys dat hierdie teks, wat die bron van die TR was, 'n sekondêre posisie in die geskiedenis van die teks inneem, nie die teks van die outograwe kan bevat nie, en gevolglik van geen belang vir die herstel van die outograwe is nie. Hiermee is die gesag van TR verbreek, deurdat Westcott en Hort op oortuigende historiese gronde bewys het dat die TR onmoontlik die teks van die outograwe kan weergee.

Die verdere aspekte van die model word nou gebruik om 'n kritiese teks, wat as alternatief vir die TR aangebied word, saam te stel. Dit word hoofsaaklik gedoen op grond van die beskrywing van die verhouding tussen die Westerse en Alexandrynse tekstipes, die oorblywende lokale tekstipes. Hulle beweer naamlik dat beide die Westerse en Alexandrynse tekstipes in die 2 de eeu ontstaan het, maar dat die Alexandrynse teks 'n meer betroubare weergawe van die oorspronklike is, omdat dit intern ' $n$ beter teks as die Westerse is. Onder die manuskripte van die Alexandrynse teks identifiseer hulle twee manuskripte, Alef en B, as sulke suiwer manuskripte, dat hulle nie aan noemenswaardige tekskorrupsie onderworpe was nie. As sodanig is 
hierdie twee manuskripte dus die mees betroubare wat beskikbaar is. Hulle teks is so suiwer, dat Westcott en Hort die lesings ten opsigte waarvan hulle ooreenstem as gelykwaardig aan die outentieke lesing beskou. Om hierdie rede bestempel hulle Alef en $B$ as neutrale manuskripte. Die gehalte van hulle teks was neutraal ten opsigte van eksterne invloede. Hulle het aan geen tekstipe behoort nie. Slegs in gevalle van Westerse non-interpolasies, waar die Westerse teks 'n kort en Alef en B saam met die Alexandrynse teks 'n lang lesing gehad het, kan die lesings van die twee neutrale manuskripte nie as neutraal bestempel word nie en is Alexandrynse invloed sigbaar. (Vgl Martini 1978: 285-296 oor die term 'neutrale teks'.)

Die metode wat Westcott en Hort gebruik het om die teks van die Griekse Nuwe Testament te herstel, het dus uit twee prosesse bestaan. Op grond van historiese getuienis word die beste manuskrip(te) geïdentifiseer. Daarna word hierdie beste manuskrip aan eksterne toetse onderwerp om te bepaal hoe betroubaar dit werklik is en in watter gevalle die lesings van die beste manuskrip nie outentiek is nie. Die eerste van die twee prosesse het gelei tot die identifikasie van Alef en $B$ as beste manuskripte, terwyl die tweede tot die vervanging van die langer lesings in Alef en B deur, byvoorbeeld, die Westerse noninterpolasies gelei het. Die metode was ' $n$ basies historiese metode, gerig op die historiese beoordeling van die waarde van manuskripte, met 'n eklektiese toets, aan die hand waarvan die lesings van die beste manuskripte indiwidueel op grond van interne getuienis getoets is. Hierdie metode het as die klassieke metode bekend gestaan (vgl Metzger 1968a: 164-165).

In die geheel van die metodiek van Westcott en Hort is dit veral die historiese aspekte wat belangrik is en waarin hulle 'n nuwe tydvak in die geskiedenis van die Nuwe-Testamentiese Tekskritiek ingelei het, omdat dit die eerste volledige, sistematiese uiteensetting van die geskiedenis van die teks ooit verteenwoordig het. Op grond hiervan het hulle bewys dat die TR 'n swak en onbetroubare teks is, deur te bewys dat die bronne waaruit dit kom, die Siriese teks, swak en onbetroubaar is, vanweë die sekondêre posisie wat dit in die tekshistoriese model ingeneem het. Hulle oorweldigende keuse van Alef en B as die beste manuskripte het uiteindelik in hulle teks neerslag gevind, aangesien die teks hoofsaaklik op hierdie twee manuskripte gebaseer was. So het die kritiese teks uiteindelik, na 'n stryd van meer as twee-en-'n-half eeue, die oorhand gekry en die TR vervang.

Die publikasie van Westcott en Hort se kritiese teks (WH) het 
onmiddellik belangstelling gaande gemaak en dit is (onder groot protes van teenstanders) vir die vertaling van die Revised Version (RV) gebruik. Met die uitsondering van die OAB sou die TR hierna, sover aan die skrywer bekend, nooit weer as grondteks vir 'n Westerse vertaling gebruik word nie. Of WH ò 'n latere kritiese teks sou vir dié doel gebruik word. Uiteindelik is WH ook as vertrekpunt gebruik vir die samestelling van die teks deur die komitee van die Verenigde Bybelgenootskappe, toe met die samestelling van die UBS-reeks, wat vandag as die mees betroubare teks beskou word, begin is (vgl Aland et al 1966: v).

Hoe betroubaar is hierdie teks? Intrinsiek beoordeel, aan die hand van die inligting wat in daardie tyd beskikbaar was, moet gesê word dat dit baie betroubaar was, aangesien die metode en tekshistoriese model ten grondslag van die teks, na 'n getroue weergawe van die werklikheid gelyk het. Dit was ook hoofsaaklik die rede waarom Westcott en Hort se teenstanders nie daarin kon slaag om hulle teorieë en teks verkeerd te bewys nie. Ekstern beoordeel is dit vandag bekend en word dit aanvaar dat Westcott en Hort op bepaalde punte nie korrek was nie. Met die ontdekking van die papiri in die middel van die 20ste eeu is ouer en meer betroubare manuskripte beskikbaar gestel en is aangetoon dat Westcott en Hort inderdaad die beste manuskripte wat aan hulle bekend was, as basis vir die teks gebruik het, maar dat die betrokke manuskripte vandag nie meer die beste is nie. Daar is ouer papiri wat ' $n$ beter teks as dié van Alef en B het. Ook blyk dit dat Westcott en Hort se historiese model te eenvoudig is en dat die geskiedenis in veral die eerste drie eeue heelwat ingewikkelder was as wat hulle voorgestel het. Waaroor daar egter steeds geen twyfel bestaan nie, is dat hulle korrek was in hulle verwerping van die TR en dat selfs hulle teks vandag nog ' $n$ veel beter en getrouer weergawe van die outograwe is as die TR. Die tekste wat vandag as die mees populêre aanvaar word, hou almal verband met $W H$ en is op een of ander wyse daarop gebaseer.

Dit is dus nie oordrewe om Westcott en Hort as die sleutelfigure in die ontwikkeling van die metodiek van die Nuwe-Testamentiese Tekskritiek te beskryf nie. Hulle werk was die kulminasiepunt van 'n ou era omdat hulle die noodsaaklike sistematisasie en integrasie aan verskillende loshangende metodologiese ontwikkelinge verskaf het. So het hulle eksterne en interne getuienis, wat implisiet en ongenuanseerd in die werk van krities-gesinde tekskritici sedert Bengel teenwoordig was, van mekaar onderskei, behoorlik gedefinieer en die waarde van elk 
aangetoon. Hulle het die bestaande indeling van manuskripte behoorlik gemotiveer en gestandaardiseer. Hulle het die indeling van manuskripte deur Bengel en andere, die genealogiese metode van Lachmann en die suggesties van ' $n$ rekonstruksie van die teksgeskiedenis deur Semler, Griesbach, en andere, geïntegreer en uiteindelik 'n gedetailleerde en gemotiveerde rekonstruksie van die geskiedenis van die teks daargestel. Binne hierdie rekonstruksie het hulle die oudste beskikbare manuskripte oortuigend as die mees betroubare geïdentifiseer en uiteindelik 'n teks daargestel wat, as gevolg van die vaste tekshistoriese basis waarop dit gestaan het, moeilik verwerp kon word. So was hulle werk die hoogtepunt en kulminasiepunt van 'n ou era.

Hulle werk was egter ook die begin van 'n nuwe kritiese era:

- Vir baie jare sou die Hortiaanse rekonstruksie van die teksgeskiedenis, besonderlik bestudeer vanuit die oogpunt van die tekstipes, die middelpunt van navorsing in die Nuwe-Testamentiese Tekskritiek bly.

- Verder het WH die tekste ná hom gedomineer, soos die teks van Erasmus die uitgawes na hóm gedomineer het. Die tekste van Nestle (Finegan 1974: 67), Merk (Epp 1974: 389), Bover (Epp 1974: 389), die UBS-reeks en $\mathrm{NA}^{26}$ is enkele voorbeelde. Hoewel daar nie 'n direkte verband tussen hierdie tekste en $W H$ in dieselfde mate as die verband van die tekste van Erasmus, Stephanus, Beza en die Elseviers aangedui kan word nie, is die meerderheid tekste wat in die 20ste eeu gepubliseer is, hoofsaaklik op die Alexandrynse teks en in besonder op Alef en B, gebaseer. Die karakter van hierdie tekste is grootliks dieselfde as dié van WH.

- In die derde plek vorm hulle uitgangspunte, metode en teksgeskiedenis steeds die kern van die gematigde eklektiese metode, wat vandag die mees populêre metode in hierdie wetenskap is.

- Laastens bied feitlik alle werke oor die metodiek van Nuwe-Testamentiese Tekskritiek vandag op een of ander stadium 'n lang bespreking van Westcott en Hort se metodiek (vgl bv Sturz 1984; Pickering 1980; Elliott 1968 - om 'n aantal van Westcott en Hort se teenstanders te noem). Dit is 'n bewys dat Westcott en Hort se metodiek en invloed vandag steeds domineer.

Westcott en Hort se werk vorm dus die hoogtepunt in die stryd teen die TR en dien terselfdertyd as die vertrekpunt van die krities-wetenskaplike benadering tot die samestelling van die teks. Hulle werk vorm die hoogtepunt van 'n ou era en terselfdertyd die begin van 'n nuwe 
era. Met hulle teks is die era van die TR afgesluit en die era van die krities-wetenskaplike teks ingelei.

Die krities-wetenskaplike gees wat Westcott en Hort in die NuweTestamentiese Tekskritiek gebring het, het spoedig die heersende benadering in die Nuwe-Testamentiese Tekskritiek geword. Waarskynlik die belangrikste gevolg van die nuwe kritiese gees wat laat in die 18 de eeu ingetree het, was dat dit ' $n$ belangrike verandering in die teksbeskouing of teksteorie teweeggebring het. Nie alleen is die gesag van die TR verbreek nie en die kritiese teks in die plek van die TR gestel nie, maar ook en veral het daar 'n nuwe gees en gesindheid ten opsigte van die teks en sy herstel in die algemeen posgevat. Vir die eerste keer in die geskiedenis van die Nuwe-Testamentiese Tekskritiek is die teks nie as iets absoluut gesien nie, maar as iets wat na aanleiding van die ontwikkeling in die metode kan verander, as iets dinamies, waaroor daar'n element van onsekerheid kan en mag bestaan. Vir die verdere ontwikkeling van die Nuwe-Testamentiese Tekskritiek het dit belangrike gevolge ingehou, deurdat dit verandering, meningsverskil en debatvoering oor die teks gestimuleer het. Die uiteinde van hierdie dinamiese benadering van die teks is in die UBS-reeks sigbaar, waar daar in die kritiese apparaat ten opsigte van elke variasie-eenheid afsonderlik aangetoon word watter mate van twyfel of sekerheid aan die oplossing van indiwiduele tekskritiese kwessies gekoppel kan word. Dit is ongetwyfeld ' $n$ belangrike uitvloeisel van die verwerping van die statiese en absolutistiese teksbeskouing van die voorstanders van die TR. Dit het ' $n$ openheid en dinamiek in die samestelling en hantering van die teks gebring en die weg geopen vir die publikasie van verskillende tekste, wat soms drasties van mekaar verskil het. Hierdie openheid het ook in die vertalings sigbaar geword, sodat dit praktyk geword het om verskillende vertalings wat ten opsigte van die aard van die vertaling, vertaalmetode of selfs die grondteks van mekaar verskil, naas mekaar te gebruik. In die geheel gesien, het hierdie benaderingsverandering ' $n$ openheid in die tekskritiese wetenskap gebring wat onontbeerlik vir die verdere ontwikkeling daarvan was.

\subsection{Van Westcott en Hort tot Streeter (1881-1930)}

Die kritiese gees wat die Nuwe-Testamentiese Tekskritiek laat in die $19 \mathrm{de}$ eeu gekenmerk het, het op die ontstaan van verskillende benaderings in die metodiek uitgeloop. Terwyl verreweg die meeste tekskritici die klassieke metode van Westcott en Hort, en in besonder hul 
rekonstruksie van die geskiedenis van die teks, probeer verfyn het, het 'n klein groepie tekskritici 'n eklektiese benadering gevolg. Soos te wagte, was daar ook kritici wat gepoog het om die TR se posisie teenoor die nuwe kritiese teks en metode te beskerm.

\subsubsection{Die klassieke metode: Van Nestle tot Streeter}

Die klassieke metode van Westcott en Hort het die verbeelding van die tekskritiese wêreld in so 'n mate aangegryp, dat elemente en aspekte daarvan die toneel vir'n lang tydperk na Westcott en Hort oorheers het. Die bestudering van die geskiedenis van die teks en die rekonstruksie van hierdie geskiedenis het die tekskritiese debat gedomineer. Sake soos die bestudering van die teksfamilies, die klassifikasie van manuskripte en die onderlinge verhouding van die teksfamilies, was aan die orde van die dag (vgl Metzger 1966/67: 372). Veral vier sake is in hierdie verband belangrik, naamlik (a) die verdere ontwikkeling van die Hortiaanse historiese model; (b) die ontdekking van die Caesareaanse teks; (c) die werk van Von Soden; en (d) die werk van Streeter.

\subsubsection{Die Hortiaanse model}

Verreweg die meeste tekskritici het hulle aandag by spesifieke aspekte van die Hortiaanse historiese model bepaal in 'n poging om hierdie model te verfyn. Tekskritici soos Eberhard Nestle, Leon Vaganey, Kirsopp Lake, Albert C Clark en Heinrich J Vogels, om maar enkeles te noem, is merkwaardige voorbeelde van hierdie groep. Hierdie tekskritici het oor die algemeen die basiese rekonstruksie van die teksgeskiedenis, soos Westcott en Hort dit daargestel het, behou en slegs detailaspekte daarvan ontwikkel. Onder hierdie groep het daar min of meer konsensus bestaan dat daar drie tekstipes onderskei moet word, naamlik die Alexandrynse, die Westerse en die Bisantynse. Westcott en Hort se konklusie ten opsigte van die Bisantynse tekstipe, dat dit eklekties uit die ander twee saamgestel is, is aanvaar. So is ook hul keuse van die Alexandrynse teks as die beste teks en in besonder hul keuse van Alef en B as die beste manuskrip bevestig. Verskeie gepubliseerde tekste uit die ongeveer halfeeu na Westcott en Hort bevestig die volgehoue voorrang van Alef en B. Nestle (vgl Finegan 1974: 67), Baljon (vgl Vaganey 1937: 173), Merk (vgl Epp 1974: 389) en Bover (vgl Epp 1974: 389) se tekste is voorbeelde. Hoewel die twee genoemde manuskripte nie meer as neutrale manuskripte beskou is nie en bloot as deel van die Alexandrynse teks beskou is, is tog 'n spesiale posisie binne hierdie teks aan hulle toegeken en is hulle steeds as besonder 
goeie manuskripte beskou. Uiteindelik het veral die ontdekking van die papiri later in die 20ste eeu meegebring dat ondersteuners van die Hortiaanse model tussen 'n Alexandrynse en proto-Alexandrynse teks onderskei het (Fee 1971: 371; Metzger 1968a: 215-216). Oor die algemeen het hierdie persone nie werklik nuwe rigtinggewende bydraes tot die ontwikkeling van die metodiek van die Nuwe-Testamentiese Tekskritiek gemaak nie. Hoewel nie nuut nie, het hulle egter tog 'n belangrike bydrae gemaak, deurdat hulle die klassieke metode gepopulariseer en verfyn het.

\subsubsection{Die Caesareaanse teks}

Waarskynlik die belangrikste ontwikkeling onder die volgelinge van Westcott en Hort in die eerste gedeelte van die 20ste eeu was die identifikasie van die Caesareaanse teks (vgl Lake, Blake \& New 1928: 211; Metzger 1963: 43-66 vir bespreking van die geskiedenis van die ontdekking van hierdie teks). Hoewel tekskritici aanvanklik gesukkel het om die presiese plek van die Caesareaanse tekstipe in die Hortiaanse model te identifiseer, was daar teen die middel van die eeu min of meer konsensus dat dit op een of ander wyse tussen die Alexandrynse en Westerse families tuishoort, 'n plek wat dit vandag steeds behou (vgl bv Metzger 1968a: 216-219).

Nie almal het egter met die identifikasie van hierdie teks saamgestem nie, met die gevolg dat daar vandag steeds talle probleme met die Caesareaanse tekstipe ondervind word. Daar bestaan oor verskillende aspekte van hierdie tekstipe, waaronder die feit van sy bestaan, nie konsensus nie (vgl Aland 1970/71: 1-9). Vir die ontwikkeling van die metodiek van die Nuwe-Testamentiese Tekskritiek is die ontdekking van hierdie teks egter betekenisvol, omdat dit die intensiewe aandag onderstreep wat in die begin van die 20 ste eeu aan die bestudering van die geskiedenis van die teks, spesifiek soos dit in die Hortiaanse rekonstruksie na vore gekom het, gegee is. In hierdie ontdekking kan die ontwikkeling en verfyning van die betrokke model duidelik gesien word.

\subsubsection{Von Soden}

In 'n enigsins ander kategorie as die tekskritici wat hierbo genoem is, val Hermann Freiherr von Soden en Burnett Hillman Streeter, waarskynlik die belangrikste tekskritici van die eerste gedeelte van die 20ste eeu. Wat Von Soden en Streeter van besondere belang maak, is die feit dat hulle binne die raamwerk van die klassieke metode, alternatiewe rekonstruksies van die geskiedenis van die teks aangebied het. 
Von Soden se belang vir die Nuwe-Testamentiese Tekskritiek lê hoofsaaklik in sy rekonstruksie van die geskiedenis van die teks (vgl Lake 1928: 78-83; Souter 1960: 120-123; Vaganey 1937: 177-181; en Metzger 1968a: 139-143 vir opsommings). Hoewel Von Soden basies dieselfde teksfamilies as Hort onderskei, stel hy hierdie families in ' $n$ ander verhouding tot mekaar. Hy verdeel naamlik die manuskripte in drie resensies, waaraan hy onderskeidelik die name Hesychiusteks (of H-teks), Jerusalemteks (of I-teks) en Koine-teks (of K-teks) gee. Sy rekonstruksie van die geskiedenis van die teks kom in hoofsaak daarop neer dat hierdie groepe na 'n verlore archetipe, wat hy die I-H-K-teks noem, teruggaan. Die archetipe is aanvanklik in een tekstipe oorgelewer, maar was op 'n baie vroeë stadium aan tekskorrupsie deur onder andere Marcion en veral Tatianus onderworpe. Resensies deur Hesychius, Pamphilius, Eusebius en Lucianus het uiteindelik daartoe gelei dat die I-H-K-teks in drie tekstipes uitmekaar gegaan het en later in drie gedefinieerde teksvorme, die I-teks, H-teks en K-teks, oorgelewer is (vgl grafiese voorstelling van Von Soden se teksgeskiedenis deur Lake 1928: 82). Die doel van die tekskritikus is dan om die archetipe van die I-H-K-teks te soek, die tekskorrupsie daarin uit te skakel, deur byvoorbeeld die lesings van Marcion en Tatianus uit hierdie archetipe te weer, en so die teks te herstel.

Die metode wat Von Soden gebruik, is nie werklik anders as die van Westcott en Hort nie. Soos Westcott en Hort soek Von Soden ook na die beste manuskrip, waarvan hy dan lesings wat ooglopend die gevolg van tekskorrupsie is, aan die hand van ander metodes regstel. Soos die geval met Westcott en Hort bepaal die rekonstruksie van die geskiedenis ook in hoofsaak die identifikasie van die beste manuskrip, terwyl die herstel van hierdie beste manuskrip aan die hand van ander aspekte van die tekskritiese metode geskied. Von Soden gebruik dus by uitstek die klassieke metode, waarvan die resensie uit sy soeke na die beste manuskrip bestaan en hoofsaaklik histories van aard is, en die emendasie uit die herstel van die beste manuskrip. Von Soden verskil egter van Westcott en Hort ten opsigte van die wyse waarop daar na die beste manuskrip gesoek moet word. Waar Westcott en Hort die tekstipes in 'n bepaalde historiese rangorde, en daarom ook implisiet voortreflikheidsrangorde plaas, stel Von Soden die drie tekstipes wat hy identifiseer, histories op min of meer dieselfde vlak. Daar is by Von Soden nie sprake van ' $n$ rangorde in die waarde van die families in dieselfde mate as by Westcott en Hort nie. Sy keuse van die beste manuskrip is gevolglik nie die resultaat van 'n eliminasieproses nie, maar eerder van 
'n eklektiese proses van die gesamentlike getuienis van die verskillende teksfamilies in sy rekonstruksie. Die resultaat van hierdie metode was uiteindelik ook' $n$ teks wat nader aan die TR gestaan het as aan Westcott en Hort se kritiese teks.

Von Soden se metodiek, met sy rekonstruksie van die geskiedenis van die teks as kern, het te radikaal van die bestaande ontwikkelingslyn in die Nuwe-Testamentiese Tekskritiek afgewyk om blywende waarde te kon hê. Gevolglik kon hy nie daarin slaag om die tekskritiese wêreld van sy rekonstruksie te oortuig nie. Tog het hy oor bepaalde aspekte, soos die klassifikasie van die minuskels, 'n waardevolle bydrae gelewer, waarvan die resultate vandag steeds in breë trekke geldig geag word en met groot vrug gebruik word.

\subsubsection{Streeter}

Streeter se historiese model is in 'n sekere sin belangriker as dié van Von Soden, omdat hy 'n geografiese, en daarom nuwe benadering tot die geskiedenis volg (vgl Vaganey 1937: 183; Metzger 1968a: 169-173 vir 'n opsomming van Streeter se werk). Die kern van Streeter se historiese model is sy teorie van lokale tekste. Hierdie teorie kom kortliks daarop neer dat daar in elke kerklike streek 'n eie (lokale) tekstipe ontstaan het, omdat die teks aanvanklik binne elke kerklike streek in 'n groot mate van isolasie oorgelewer is, met die gevolg dat eiesoortige en onafhanklike lesings in die manuskripte van elke streek ontstaan het. Hy identifiseer lokale tekste in die volgende gebiede: Alexandrië; die Ooste, waar twee lokale tekste voorgekom het, naamlik in Caesarea en Antiochië; en die Weste, waar ook twee voorgekom het, naamlik in Italië en Kartago. Later het daar egter ' $n$ tendens ontwikkel om 'n akkurate en getroue teks te gebruik. In hierdie proses het die kleiner kerksentra manuskripte by die groter kerksentra in hul metropolitaanse gebiede gekry en op hierdie wyse sou die lokale tekste van die kleiner sentra met dié van die groter sentra assimileer. Uiteindelik het ook die groter kerksentra hulle tekste met mekaar vergelyk in ' $n$ poging om 'n teks daar te stel wat algemeen aanvaar kon word. Op hierdie wyse het die Bisantynse teks tot stand gekom.

Op grond van hierdie model identifiseer Streeter die beste manuskrip. Omdat die grootste mate van diversiteit onder die lokale tekste vroeg in die 3de eeu voorgekom het, moet die tekskritikus in sy poging om die beste manuskrip te vind, die archetipe van die verskillende lokale tekste identifiseer. Om dit te kan doen, is dit egter noodsaaklik om eers die teks van elke lokale tekstipe te identifiseer of te rekon- 
strueer. Op grond van hierdie rekonstruksies moet die archetipe uiteindelik gerekonstrueer word.

Streeter se metodiek bevat elemente van sowel Westcott en Hort as Von Soden. Met Westcott en Hort stem Streeter in breë trekke ooreen ten opsigte van die identifikasie van die tekstipes waarmee hy werk. Hoewel Streeter met vyf tekstipes, naamlik dié van Alexandrië, Caesarea, Antiochië, Italië en Kartago werk, deel hy hierdie tekstipes in drie groter groeperinge in, naamlik ' $n$ Oosterse, Westerse en Alexandrynse. Die Alexandrynse teks in Streeter se teorie is dieselfde as Westcott en Hort se Alexandrynse teks. Streeter se Westerse teks is dieselfde as Westcott en Hort se Westerse teks, terwyl Streeter se Oosterse teks basies die nuutgeïdentifiseerde Caesareaanse teks is. Dit is gevolglik slegs in hierdie laaste opsig dat Streeter by die nuwe ontwikkelinge van sy tyd, waarby hy self baie nou betrokke was, aansluit en Westcott en Hort se model verfyn. Ook Streeter se teorie in verband met die Bisantynse teks, naamlik dat dit na 'n standaardiseringsproses uit die ander tekste ontstaan het, klop in breë trekke met Westcott en Hort se teorie oor die Siriese teks. In wese is daar dus nie veel verskil tussen Streeter en Westcott en Hort nie. Streeter het Westcott en Hort se rekonstruksie verfyn deur dit binne 'n geografiese konteks te plaas.

Waar daar egter tog ' $n$ verskil tussen Westcott en Hort en Streeter is, is die wyse waarop daar van hierdie rekonstruksie na die identifikasie van die beste manuskrip en uiteindelik die herstel van die teks beweeg word. In hierdie opsig sluit Streeter weer by Von Soden aan. Soos Von Soden se identifikasie van die beste manuskrip op die herstel van die I-H-K-teks gegrond was, so is Streeter se identifikasie van die beste manuskrip uiteindelik gegrond op die herstel van die archetipe van die verskillende tekstipes in sy model. Waar Westcott en Hort se rekonstruksie van die geskiedenis direk op die identifikasie van 'n beste manuskrip uitgeloop het, het Streeter se metodiek, soos dié van Von Soden, nie uitgeloop op die direkte identifikasie van die archetipe nie. 'n Tussenstap, die herstel van die teks van elke lokale tekstipe, word as belangrike voorvereiste vir die herstel van die archetipe waaruit die lokale tekste ontstaan het, bygevoeg. Soos Von Soden se metode in werklikheid slegs sukses kon behaal indien daar met die archetipe van elke familie gewerk word as basiselemente in die bepaling van die I-H-K-teks, so werk Streeter ook met die beste manuskrip van elke familie in ' $n$ poging om die uiteindelike beste manuskrip ten opsigte van die oorspronklike teks te bepaal. Streeter verskil egter ten opsigte van die rekonstruksie van die teksgeskiedenis van Von Soden daarin 
dat Streeter die Bisantynse teks uitsonder as 'n laat en eklektiese teks, soos Westcott en Hort, en aan hierdie teks gevolglik nie 'n gelyke plek saam met die ander ouer tekstipes in sy rekonstruksie toeken nie.

Soos die geval met Von Soden se metode kan hierdie metode, indien dit konsekwent toegepas word, nie 'n ander resultaat lewer as 'n eklektiese teks nie, omdat Streeter basies geografies werk en op eklektiese wyse 'n beste manuskrip moet identifiseer. Omdat Streeter nie 'n teks gepubliseer het nie, kan die resultate van sy metodiek nie getoets word nie.

\subsubsection{Die eklektiese benadering: Van Bèdier tot Lagrange}

Een van Westcott en Hort se tydgenote en kritici, Josef Bèdier, het kritiek teen Westcott en Hort se gebruik van genealogiese getuienis uitgespreek, en begin om een aspek van hulle metodiek, die oorweging van interne getuienis van lesings, soos dit genoem is (Westcott en Hort 1974: 10), verder te ontwikkel. Hy het naamlik eklekties te werk gegaan deur sy keuse van die beste manuskrip op interne gronde te baseer en hierdie manuskrip dan sporadies aan die hand van die lesings in ander manuskripte te korrigeer (Metzger 1968a: 159). Bèdier was nie 'n konsekwente eklektikus nie, omdat hy ook die klassieke metode se twee onderdele, resensie en emendasie, gebruik het. Wat hom anders as die voorstanders van die klassieke metode maak, is die feit dat hy die beste manuskrip, nie op grond van historiese getuienis nie, maar op grond van interne getuienis kies. Bernhard Weiss sluit in sy metode by Bèdier aan, deurdat hy van hoofsaaklik eksegetiese getuienis gebruik maak om die beste manuskrip te kies (Epp 1976: 250; Metzger 1968a: 137). Hierdie metode bring hom by die gevolgtrekking dat $B$ die beste manuskrip is en dat hierdie manuskrip, met die uitsondering van 'n aantal kleinighede, min foute bevat. Hy baseer sy teks uiteindelik op B (Vaganey 1937: 173). Tot 'n mindere mate maak ook M-J Lagrange van so 'n eklekties-klassieke metode gebruik (vgl Colwell 1969: 6; Epp 1976: 250).

Waarskynlik die belangrikste figuur in die ontwikkeling van die eklektiese benadering is egter $\mathrm{CH}$ Turner. Turner breek heeltemal met die soeke na die beste manuskrip van die klassieke of eklektiesklassieke metode deur die bekende uitgangspunt van Westcott en Hort: 'Knowledge of documents should precede final judgement upon readings' (Westcott \& Hort 1974: 31), te verander na: 'Knowledge of author's usage should precede final judgement' (aangehaal deur Epp 1976: 250-251). In 'n reeks artikels oor die taalgebruik en styl van Markus tussen 1924 en 1928 pas hy hierdie metode toe, deur hoofsaaklik van 
interne, veral stilistiese en filologiese aspekte, vir die oplossing van tekskritiese probleme gebruik te maak (vgl o a Turner 1924: 377-386; 1925: 12-20; 1927: 145-158; ook Metzger 1968a: 176; Epp 1976: 250251). Turner was voor George D Kilpatrick en J Keith Elliott later in die 20ste eeu die enigste werklike konsekwente eklektikus in hierdie wetenskap en sowel Kilpatrick as Elliott sluit by hom aan in hulle gebruik van hierdie metode.

\subsubsection{Voorstanders van die TR: Van Burgon tot Hills}

Soos verwag kan word, het die voorstanders en ondersteuners van die TR die nuwe ontwikkelinge en kritiese teks nie gelate aanvaar nie. Gevolglik kom 'n derde rigting in die Nuwe-Testamentiese Tekskritiek in die laaste gedeelte van die 19de eeu uit die kring van die voorstanders van die TR, wat skerp op die metodiek van Westcott en Hort gereageer het in ' $n$ poging om die gesagsposisie van die TR te handhaaf. ' $n$ Tydgenoot van Westcott en Hort, John W Burgon, is die bekendste en belangrikste eksponent van hierdie rigting in die laat $19 \mathrm{de}$ eeu (vgl Burgon 1883; 1896a; 1896b). Soos die ontwikkeling van die metodologiese benadering in Westcott en Hort se werk 'n hoogtepunt bereik het, so het die teenstand teen die kritiese teks en metodologiese benadering in Burgon se werk ' $n$ hoogtepunt bereik. Naas Burgon verdien die name van FHA Scrivener (vgl Scrivener 1894) en HC Hoskier ook gemeld te word as voorstanders van die TR. Hoskier se monumentale ontleding van die verskille tussen Alef en B in 'n poging om hulle te diskrediteer, staan uit onder hierdie kritici se werk (vgl Hoskier 1914). Nie een van Burgon, Scrivener of Hoskier kon egter daarin slaag om Westcott en Hort se teorieë te weerlê nie, hoofsaaklik omdat nie een van hulle die beginsels van die klassieke metode in besonder of die metodologiese benadering in die algemeen in hulle kritiek gevolg het nie. Gevolglik het daar feitlik niks oorspronkliks en blywends ten opsigte van die metodiek van die Nuwe-Testamentiese Tekskritiek uit hierdie rigting voortgekom nie. Later in die 20 ste eeu was EF Hills 'n laaste woestynstem teen die krities-metodologiese benadering van Westcott en Hort (vgl Hills 1956).

\section{DIE TEXTUS ECLECTICUS (20ste eeu)}

Die laaste tydperk in die geskiedenis van die metodiek van die Nuwe-Testamentiese Tekskritiek, die eklektiese periode, strek oor die 
laaste gedeelte van die 20ste eeu. Anders as met die ander twee tydperke, is dit moeilik om 'n presiese datum vir die begin van hierdie tydperk voor te stel, aangesien elemente van die verskillende metodes wat in die tweede gedeelte van die 20 ste eeu gebruik word, reeds vroeër in die 20ste eeu bestaan het. Die ontdekking van die papiri kan egter as keerpunt in die Nuwe-Testamentiese Tekskritiek in die 20ste eeu beskou word. Daarom word die dertigerjare, ná die ontdekking van die Chester Beatty-papiri, as die beginpunt van hierdie tydperk beskou (vgl bv Epp 1980: 135-137; Metzger 1966/67: 372; Klijn 1960/61: 168; Colwell 1969: 45; Aland 1965: 334; 1957a: 163). Hierdie keerpunt het in besonder die perspektief waarmee die geskiedenis van die teks bestudeer is, geraak en het uiteindelik belangrike gevolge vir sowel die rekonstruksie van die geskiedenis van die teks, die metode vir die herstel van die teks, as die teks self, ingehou. So het die papiri die metodologiese aangesig van hierdie wetenskap verander (vgl ook Colwell 1969: 45; Epp 1980: 145).

\subsection{Die geskiedenis van die teks}

So oortuigend was die Hortiaanse historiese model gekonstrueer, dat aanvanklik, na die ontdekking van die papiri, aanvaar is dat die papiri, hoewel veel ouer as die manuskripte waarop die Hortiaanse model gebaseer was, netjies binne die raamwerk van die Hortiaanse model sou pas en die model dus sou bevestig. Die ontdekking van die Chester Beatty-papiri in 1930 en die Martin Bodmer-papiri in 1956-60 het egter 'n geskarrel in die duiwehok veroorsaak en ernstige leemtes in die Hortiaanse model ontbloot. Pogings om die papiri in die bestaande teksfamilies in te deel, het geblyk vrugteloos te wees. Die aanvanklike hantering van die Chester Beatty-papiri is 'n goeie illustrasie hiervan. $P^{45}$ is byvoorbeeld as ' $n$ Caesareaanse manuskrip geklassifiseer, hoewel dit duidelik nie 'n 'suiwer' Caesareaanse teks gehad het nie. Hierdie klassifikasie van $\mathrm{P}^{45}$ het egter reeds 'n klein verstellinkie aan die bestaande rekonstruksie genoodsaak en het daartoe gelei dat onderskei moes word tussen die pre-Caesareaanse teks en die Caesareaanse teks (vgl Lake \& Lake 1941: 7-8). Die naam 'pre-Caesareaans' self is reeds 'n aanduiding van die probleem. Die term impliseer die bestaan van 'n soort Caesareaanse teks voordat die Caesareaanse teks bestaan het en is dus anachronisties van aard. Hierdie benaming was egter nodig omdat $\mathrm{P}^{\mathbf{4 5}}$ ouer as ander Caesareaanse manuskripte was, hoewel dit, aan die een kant, oor genoeg eienskappe beskik het om as Caesareaans geklas- 
sifiseer te word, maar, aan die ander kant, oor soveel non-Caesareaanse eienskappe beskik het, dat dit nie volledig binne hierdie tekstipe gepas het nie. In hierdie benaming kan daar dus reeds iets gevind word van die feit dat die papiri as gemengde tekste bestempel moes word, indien hulle vanuit die perspektief van die teksfamilies bestudeer word. $\mathrm{P}^{45}$ het, met ander woorde, nie heeltemal binne die raamwerk van die bestaande teksfamilies gepas nie, en is gevolglik as 'n gemengde teks beskou. Tot op hierdie stadium was dit egter nog geen krisis nie, omdat die bestaan van gemengde manuskripte nie problematies in hierdie wetenskap is nie.

Die ontdekking van die Bodmer-papiri in 1956-1960 het die aandag baie pertinent by die papiri bepaal en tekskritici gedwing om die perspektief waarmee die geskiedenis van die teks bestudeer word, te verander. Hoewel hierdie manuskripte aanvanklik ook as gemeng bestempel is (vgl King 1964: 56, t o v P72; Metzger 1961/62: 202 t o v P75; Klijn 1971: $250-251$ t o v $\mathrm{P}^{66}$ ), is spoedig besef dat so 'n tipering nie houdbaar is nie. Dit is veral Aland wat in verskeie publikasies aangetoon het dat dit nie korrek is om die Bodmer-papiri as gemeng te tipeer nie, omdat hulle op hierdie wyse in terme van die teksgeskiedenis van die 4 de eeu en later beskryf word, terwyl hulle self ouer as die 4 de eeu is. Aland maak hieruit die afleiding dat hierdie manuskripte die teksfamilies voorafgaan en waarskynlik eerder impliseer dat die teksfamilies nie so oud is as wat aanvaar is nie. Gevolglik dui die tekskarakter van hierdie manuskripte eerder op die bestaan van 'n vroeë teks, waaruit die teksfamilies later ontwikkel het (Aland 1967: 89-92; 1970/71: 1-4; 1979: 4; 1957b: 590; 1965: 334-337). Metzger (1961/62: 203) maak dieselfde afleiding as Aland uit die nie-klassifiseerbaarheid van die papiri.

Aland se teorie weerspieël die verandering in perspektief duidelik. In plaas daarvan dat die papiri se 'onvermoë' om binne die bestaande model(le) van teksfamilies geakkommodeer te word as 'n refleksie op die tekstuele integriteit van hierdie manuskripte geag word, word die geldigheid van die bestaande modelle eerder bevraagteken, omdat die papiri ouer is as die manuskripte waarop die modelle gebaseer is en gevolglik nie binne so 'n raamwerk hoef te pas nie. Die fout lê dus nie by die papiri, soos aanvanklik gemeen is nie, maar by die bestaande modelle. Die verwysingspunt in die rekonstruksie van die geskiedenis van die teks het dus van die 4 de eeu na die 2 de/3de eeu verskuif. Spesifiek die Bodmer-papiri was vir hierdie verandering in perspektief verantwoordelik, omdat dit juis hierdie manuskripte is wat aangetoon 
het dat die vermenging in die Chester Beatty-papiri in werklikheid geen vermenging is nie, maar eerder die gevolg van ' $n$ valse paradigma of perspektief in die bestudering van hierdie manuskripte is.

Die genoemde verandering in perspektief en verskuiwing van die verwysingspunt van die rekonstruksie van die geskiedenis van die teks het ' $n$ vars evaluering van die Hortiaanse model, wat steeds in die middel van die 20ste eeu die mees populêre model was, meegebring, deurdat hierdie model nou vanuit die perspektief van die 2 de/3de eeu benader kon word. Twee standpunte het in hierdie nuwe evaluering van Westcott en Hort voorgekom. Enersyds was daar tekskritici wat gemeen het dat die papiri die Hortiaanse model in breë trekke bevestig het (vgl bv Delobel 1977: 322-323; Black 1977: 120; Porter 1967: 71; Junack 1978: 132-133; Epp 1974: 397-398; en die rekonstruksies deur Fee 1978b: 27-29; Metzger 1968a: 212-219), terwyl ander tekskritici weer gemeen het dat die Hortiaanse model in die lig van die papiri problematies is en gevolglik deur ' $n$ nuwe model vervang moet word (vgl Aland 1959: 730; 1965: 346; Clark 1968: 159-167; 1962: 17-19; Filson 1957: 61; Klijn 1956/57: 327; 1960/61: 161-164; Birdsall 1960: 10).

Onder die eerste groep tekskritici wat hierbo genoem is, word twee groeperinge aangetref. 'n Deel beklemtoon hoofsaaklik Westcott en Hort se keuse van Alef en $B$ as die beste manuskrip en nie soseer hulle rekonstruksie van die geskiedenis van die teks as sodanig nie (Delobel 1977: 322-323; Junack 1978: 132-133). Hierdie standpunt sentreer in hoofsaak daarom dat Westcott en Hort korrek was in hul keuse van Alef en $B$ as beste manuskrip, omdat die verband tussen die papiri, veral $P^{75}$, en hierdie manuskripte, veral B (vgl o a Fee 1968; Zuntz 1953; Porter 1967), bewys dat Alef en B'n besonder ou teks het, wat teruggaan tot in die 2 de/3de eeu, en gevolglik'n besondere goeie kwaliteit teks het. Oor die vraag of die papiri hierdie aspek van die Hortiaanse model, wat in wese die resultaat van die model is en nie deel van die model self nie, bevestig of nie, bestaan daar egter weinig verskil onder tekskritici. Daar is min of meer konsensus dat Westcott en Hort inderdaad korrek was met hul keuse van die beste manuskrip. Hierdie standpunt raak dus nie die kern van die saak nie.

Die tweede groep onder tekskritici wat meen dat die papiri die Hortiaanse model bevestig, gaan verder as bogenoemde deur te beweer dat die papiri ook die model self bevestig. Tekskritici soos Metzger (vgl Metzger 1968a: 212-219), Fee (vgl Fee 1978b: 27-29) en Porter (vgl Porter 1967: 71) behou steeds die basiese elemente van die Hortiaanse model en pas gewoon die papiri by hierdie elemente in. Mertzger se 
bespreking van die papiri (Metzger 1968a: 247-255), waarin hy telkens probeer om die papiri by een van die bestaande families te klassifiseer, is 'n goeie voorbeeld hiervan. Hierdie tekskritici verfyn bloot die Hortiaanse model deur byvoorbeeld tussen 'n proto-Alexandrynse en 'n Alexandrynse teks enersyds, en ' $n$ pre-Caesareaanse en Caesareaanse teks andersyds, te onderskei (Metzger 1968a: 214-216). Die genoemde onderskeidinge en identifikasie van subtekstipes word gedoen om die gemengde karakter van die papiri saam met hulle ouderdom binne die Hortiaanse model te akkommodeer. Hierdie aanpassings van die Hortiaanse model herinner aan Strester se identifikasie van subtekstipes binne sy groot lokale tekste. Dit is ook nie toevallig dat twee van die moderne subtekstipes, die Caesereaanse en pre-Caesareaanse, juis hul oorsprong by Streeter gehad het nie. In breë trekke volg hierdie tekskritici steeds die Hortiaanse model, deurdat hulle geen alternatief voorstel nie, maar bloot fyner onderskeidinge binne hierdie model tref en op hierdie wyse die standpunt dat die papiri die Hortiaanse model bevestig, motiveer.

Onder die tekskritici wat meen dat die papiri 'n totale alternatief vir Westcott en Hort vereis, is die stem van Aland, wat bekend is vir sy uitgebreide en noukeurige bestudering van die papiri, prominent. Die kern van hierdie standpunt lê juis in die feit dat die papiri nie volledig binne die bestaande families geklassifiseer kan word nie. Die papiri kan gevolglik nie as primêre getuienis van elke teksfamilie beskou word nie, nieteenstaande die feit dat die ouderdom van hierdie manuskripte hulle van primêre belang vir die Nuwe-Testamentiese Tekskritiek maak. Gevolglik word die waarde van die papiri gerelativeer. Waar tekskritici wat glo dat die papiri die Hortiaanse model basies bevestig, meen dat hierdie verskille nie groot genoeg is om radikale veranderinge aan die model te maak nie, meen Aland dat die verskille so groot en van so ' $n$ aard is dat die model in geheel hersien moet word, omdat daar geen werklike verband tussen die papiri en die bestaande lokale tekste bestaan nie. Die papiri kom dus uit 'n tydperk voordat die tekstipes wat Westcott en Hort identifiseer, bestaan het, of ten minste voordat hierdie tipies so noukeurig van mekaar onderskei kon word. Vir Aland relativeer die papiri dus die Hortiaanse model, aangesien dit aantoon dat hierdie model ongeldig, of ten minste dan nie meer relevant vir die geskiedenis van die teks voor die 4 de eeu is nie. Waar die eerste groep dus meen dat die papiri aantoon dat die teksfamilies ouer is as wat Westcott en Hort kon bewys, meen Aland dat hulle nie so oud is as wat vermoed is nie. Gevolglik eis die papiri dat 
die geskiedenis van die teks in ten minste die eerste drie eeue van oorlewering herskryf word.

Om in hierdie behoefte te voorsien, bied Aland self ' $n$ alternatiewe model (vgl Aland 1981: 257-275; 1982: 43-59; Aland \& Aland 1982: 57-83), wat in 'n groot mate van sowel die Hortiaanse model as die modelle van Metzger en Fee verskil: Voor die ontstaan van die lokale tekstipes in die 3de/4de eeu is die teks by wyse van 'n 'ongekontroleerde oorlewering' oorgelewer. In hierdie tydperk is dit nie moontlik om enige vorm van lokale tekstipes te identifiseer nie. Dit is wel moontlik om die manuskripte van hierdie vroeë teks op grond van hulle tekstuele karakter en integriteit te klassifiseer en om kwalitatiewe tekstipes onder hierdie manuskripte te identifiseer. Aland identifiseer drie sulke tekstipes, naamlik 'n Vaste teks, wat 'n betroubare teks bevat het en die outograwe noukeurig oorgelewer het, 'n Normaalteks, wat die outograwe met bepaalde afwykings, wat baie lank in die manuskripte van die Nuwe Testament voorkom, oorlewer, en 'n Vrye teks, wat baie meer afwykings as die Normaalteks bevat en as sodanig ' $n$ meer ongekontroleerde oorlewering veronderstel (Aland \& Aland 1982: 103; Aland 1981: 263). Teen die einde van die 3de en begin van die 4 de eeu het die lokale tekstipes ontstaan. Hiervan onderskei Aland drie, 'n Alexandrynse (soortgelyk aan Metzger et al se proto-Alexandrynse teks), wat na 'n resensieproses in 'n Egiptiese teks oorgaan (soortgelyk aan Metzger et al se Alexandrynse teks); 'n Koine-teks (soortgelyk aan die Bisantynse teks); en 'n D-teks (soortgelyk aan die Westerse teks). Die Koine-teks het na 'n standaardiseringsproses uit die ander tekstipes ontstaan.

Die verskille tussen Aland en Westcott en Hort se modelle is duidelik. Die belangrikste verskil is dat Aland in sy model voorsiening maak vir ' $n$ vroeë periode van oorlewering, waarin die tekstipes heeltemal anders as in die Hortiaanse model gedefinieer word. Op hierdie wyse dateer hy die lokale tekstipes, wat die kern van die Hortiaanse model gevorm het, heelwat later as wat dit in die Hortiaanse model gedateer word. Daar is egter ' $n$ belangrike ooreenkoms tussen die twee modelle. Dit is die posisie van die Bisantynse teks, of Koine-teks, soos Aland verkies om dit te noem. Dit behou ook in Aland se model sy sekondêre posisie met die gevolg dat ook Aland se historiese model geen verandering in die waarde van hierdie teks vir die herstel van die outograwe suggereer nie.

Om op hierdie stadium ' $n$ keuse tussen die modelle van Metzger en Aland te maak, is baie moeilik. Hoewel dit tans voorkom of Aland se 
model 'n meer akkurate weergawe van die geskiedenis kan wees, hoofsaaklik omdat hy die geskiedenis vanuit die perspektief van die papiri rekonstrueer, is daar aan beide modelle 'n mate van onsekerheid verbonde. Beide hierdie modelle is nog in 'n ontwikkelingsfase en veral Aland se model gaan mank aan gedetailleerde beskrywings en gefinaliseerde definisies.

Hoewel feitlik alle tekskritici dus gesien en erken het dat die Hortiaanse model in die lig van die getuienis van die papiri nie meer in alle besonderhede geldig is nie, ag die meerderheid tekskritici 'n konserwatiewe hersiening, waarin slegs sekere aspekte van die Hortiaanse model hersien word, voldoende. Net Aland het tot dusver gewaag om die model in geheel te bevraagteken, en ' $n$ radikale alternatief te stel.

Die vraag kan onmiddellik gestel word waaraan die konserwatiewe reaksie van die meerderheid tekskritici toegeskryf kan word. Daar is waarskynlik twee faktore ter sprake:

- In die eerste plek moet in ag geneem word dat daar maar ongeveer 25 jaar verloop het sedert hierdie manuskripte ontdek is. Dit is te wagte dat daar nie sonder meer na enige alternatief gegryp sou word in so 'n kort tydperk nie. Die papiri het getoon dat die teksgeskiedenis meer kompleks is as wat 50 jaar gelede vermoed is en die konserwatiewe reaksie onder tekskritici kan daaraan gewyt word dat tekskritici versigtig is om 'n komplekse probleem op'n simplistiese wyse op te los en sodoende ' $n$ verkeerde weg in te slaan.

- Daar is egter waarskynlik ' $n$ belangriker rede vir hierdie gebrek aan 'n oortuigende alternatief, naamlik 'n gebrek aan voldoende bronne waaruit so 'n alternatief oortuigend gerekonstrueer kan word. Daar is te min manuskripte voor die 4de eeu beskikbaar om eksplisiete oortuigende afleidings ten opsigte van die karakter van die teks in die eerste aantal eeue te verseker. Die manuskripte voor die 4 de eeu is so fragmentaries dat dit slegs in Johannes 10 en 11 is waar drie manuskripte $\left(\mathrm{P}^{45}, \mathrm{P}^{66}\right.$ en $\left.\mathrm{P}^{75}\right)$, en in enkele ander dele van dieselfde Evangelie is waar twee manuskripte $\left(\mathrm{P}^{66}\right.$ en $\mathrm{P}^{75}$ ) oorvleuel. Dit is onmoontlik om die geskiedenis van die teks oortuigend op grond van so min gegewens te rekonstrueer. Wanneer hierby gevoeg word dat al die papiri wat bekend is uit Egipte afkomstig is, en dat daar steeds geen primêre Griekse getuienis in die vorm van manuskripte uit die Weste, Griekeland of die Midde-Ooste voor die 4de eeu beskikbaar is nie, word die saak nog meer ingewikkeld. Dit maak dit 
nog moeiliker om pertinente afleidings ten opsigte van die geskiedenis van die teks, veral buite Egipte te maak. Tog is hierdie papiri voldoende om die onhoudbaarheid van die bestaande modelle aan te toon, aangesien daar genoeg manuskripte uit die 4 de eeu en later beskikbaar is, waarmee hierdie manuskripte vergelyk kan word. Hoewel daar dus voldoende getuienis is om die bestaande oortuigend te bevraagteken, is daar te min getuienis om ' $n$ alternatief te bied. Dit is vandag die krisis waarin tekskritici hulself bevind en waarbinne hulle die geskiedenis van die teks moet rekonstrueer ten einde die teks te herstel.

\subsection{Die metode en teks}

Die krisis in die rekonstruksie van die geskiedenis van die teks het ook die metode waarvolgens die teks herstel is, in gedrang gebring. Tot op hierdie stadium het, met enkele uitsonderings, die keuse van die beste manuskrip die kern van die metode vir die herstel van die teks gevorm. Die probleme met die geskiedenis van die teks, wat normaalweg die basis vir die keuse van die beste manuskrip gevorm het, het meegebring dat die beste manuskrip nie meer so oortuigend soos voorheen as die beste en mees betroubare beskou kon word nie. Die gevolg is dat die beste manuskrip ook nie meer in dieselfde mate as voorheen die kern van die metode vir die herstel van die teks kon vorm nie. Hierdie wantroue in die ou historiese modelle, saam met die onvermoë om oortuigende alternatiewe te stel, het uiteindelik meegebring dat die sluimerende metodologiese verskille van die eerste gedeelte van die 20ste eeu op die spits gedryf is. Die gevolg is dat daar vandag vir die eerste keer in hierdie wetenskap se geskiedenis werklik 'n verskeidenheid metodes gebruik word om die teks van die Griekse Nuwe Testament te herstel:

- 'n Samesmelting van die klassieke metode en die eklektiese benadering (veral die eklekties-klassieke eksponent daarvan) loop uit op dit wat vandag as die gematigde eklektisisme (reasoned eclecticism) bekend geword het. Hierin speel die klassieke element vandag 'n al kleiner rol, terwyl 'n al groter rol aan die eklektiese element toegeken word.

- Die konsekwente eklektiese metode van Turner loop uit op die huidige radikale eklektisisme (thoroughgoing of rigorous eclecticism).

- Ten slotte word die voorstanders van die TR se rigting laat in die 
sewentiger jare deur 'n nuwe benadering voortgesit, waarin die behoud van die meerderheidsteks beklemtoon word.

\subsubsection{Gematigde eklektiese tekste - UBS/NA ${ }^{26}$}

Die toestand ten opsigte van die rekonstruksie van die geskiedenis van die teks het meegebring dat daar onder die volgelinge van Westcott en Hort belangrike aanpassings ten opsigte van die metode gemaak moes word. Hoewel die aanpassings noodgedwonge is en daar vandag waarskynlik nie 'n ander werkbare alternatief is nie, is die gematigde eklektiese metode egter problematies omdat dit inherente swakhede het, wat meebring dat dit, relatief gesien, nie sulke betroubare resultate kan bied as wat Westcott en Hort se metode gebied het nie. Die gevolg is dat die tekste wat vandag algemeen gebruik word en aan die hand van hierdie metode saamgestel is, by name $\mathrm{UBS}^{3}$ (Aland et al 1975; 1983) en $\mathrm{NA}^{26}$ (Aland et al 1979) minder seker is as die tekste wat 100 jaar gelede gebruik is, ofskoon dit vandag duidelik is dat laasgenoemde tekste self onbetroubaar is. Om hierdie stelling te motiveer, is dit nodig om Westcott en Hort se metodologiese model met dié van gematigde eklektici te vergelyk.

Westcott en Hort se metode het oortuigende resultate gebied omdat die kern daarvan, die historiese getuienis, 'n groot mate van sekerheid kon bied. Die gerigtheid van die metode was op die manuskripte. Twee manuskripte is naamlik op grond van die rekonstruksie van die geskiedenis van die teks geïdentifiseer as synde die mees betroubare of beste manuskripte en die teks is hoofsaaklik op hierdie twee manuskripte gebaseer. Voorts was met redelike sekerheid aanvaar dat die oordeel ten opsigte van die keuse van die beste manuskrip korrek was, dat hulle inderdaad betroubare manuskripte was en dat die lesings in die manuskripte dus vertrou kan word, omdat die historiese model ten grondslag van hulle keuse oortuigend was. Niks was beskikbaar om aan te toon dat Westcott en Hort die beskikbare feite (die historiese gegewens uit die bronne wat tot hulle beskikking was) verkeerd geïnterpreteer en verkeerd in die metodiek verdiskonteer het nie. Die historiese model, wat die kern van die metode gevorm het, en die resultaat daaruit, die keuse van Alef en B as manuskripte waarop die teks gebaseer moet word, was akkuraat en betroubaar. Daarom was ook die teks in die lig van die feite wat beskikbaar was, betroubaar.

Die ontdekking van die papiri het egter juis hierdie punt, die akkuraatheid van die historiese model, bevraagteken en getoon dat dit 
in der waarheid nie akkuraat is nie. So het ook die keuse van Alef en B as beste manuskrip onseker geword. Die logiese stap onder sulke omstandighede is om bloot die onsekerheid uit die kern van die metode weg te neem, en met 'n meer seker kern te vervang, dit wil sê om die Hortiaanse historiese model met ' $n$ ander meer akkurate te vervang. Soos hierbo aangetoon is dit egter nie moontlik nie. Daarom is Metzger konserwatief in sy aanpassing van die historiese model, is Aland se meer radikale aanpassing onafgerond en is beide modelle nie heeltemal oortuigend nie.

Omdat die onakkurate historiese model nie met ' $n$ nuwe oortuigende vervang kan word nie, is die kern van die metode dus onseker, tot so 'n mate dat Westcott en Hort se metode nie meer bruikbaar is nie en dat ook die metode se resultate nie meer betroubaar geag kan word nie. Die gevolg hiervan is weer dat die metode in geheel aangepas moes word, omdat die kern van die ou metode nie met 'n nuwe oortuigende vervang kon word nie. Die uiteindelike gevolg van hierdie probleme is dat daar in die aanpassing van die metode ' $n$ totale verskuiwing in die balans van die metode plaasgevind het. Waar die kern van Westcott en Hort se metode op die identifikasie aan die hand van historiese getuienis van 'n beste manuskrip, wat die kern van die herstelde teks gevorm het, gerig was, is die kern van die gematigde eklektiese metode nou op die identifikasie van die beste lesing binne elke variasieeenheid, aan die hand van historiese en ander getuienis, gerig. Gevolglik is die kwessie van die identifikasie van die beste manuskrip maar een van die kriteria wat in die herstel van die teks gebruik word en nie meer die sentrale kriterium nie. Op hierdie wyse het die aard van die metode verskuif van 'n basies historiese metode (met historiese getuienis as kern), waarvan die resultate eklekties (deur die gebruik van interne getuienis) gekontroleer word, na 'n basies eklektiese metode (wat bestaan uit 'n stel kriteria) wat soms histories getoets word (in die kader van die geskiedenis van die teks geinterpreteer word). Waar die gerigtheid in Westcott en Hort se metode op die manuskripte was en die indiwiduele lesings van sekondêre belang was, is die gerigtheid van die eklektiese metodes op die lesing, wat in die lig van die historiese getuienis geëvalueer word. Dit is dus duidelik wat plaasgeving het: Omdat die historiese getuienis, wat die kern van die ou metode gevorm het, onbetroubaar geraak het, is dit uit die kern weggeneem en word dit ter wille van die element wat gewoonlik as kompensasie vir gebreke in die historiese getuienis gedien het (interne getuienis), onderbeklemtoon - dit terwyl die kompenserende element, 
die interne getuienis, nie ontwikkel is nie en vandag steeds op dieselfde wyse as 100 of 150 jaar gelede in die metode verdiskonteer word.

Hierdie verskuiwings in die metode het uiteraard ook die resultaat daarvan beïnvloed en die betroubaarheid van die teks geraak. Die gevolg is dat die tekste wat aan die hand daarvan saamgestel is en vandag algemeen gebruik word, relatief gesien minder betroubaar is as wat die tekste van 100 jaar gelede in hulle tyd was, terwyl dit duidelik is dat daardie tekste vandag nie meer betroubaar geag kan word nie. Dit lyk of die Nuwe-Testamentiese Tekskritiek homself in 'n soort skaakmatposisie bevind: Daar is voldoende materiaal om te bewys dat ouer tekste nie betroubaar is nie, terwyl daar te min materiaal is om meer betroubare tekste saam te stel. Die teks van die Griekse Nuwe Testament is dus vandag as 't ware in onsekerheid gehul: Daar is redelike groot sekerheid dat UBS en $\mathrm{NA}^{26}$ in die regte rigting beweeg, dat dit ten minste die teks van die 2 de eeu verteenwoordig, waarskynlik in die algemeen gesien, die karakter van die outograwe het en dat dit daarom die beste tekste is wat beskikbaar is; daar is egter oor detailaspekte van die tekste, oor bepaalde variante lesings self, onsekerheid. Hierdie stelling kan gemotiveer word deur 'n ontleding van die waarderingsisteem van die lesings in UBS $^{3}$ te maak. Daar is naamlik bereken dat in totaal $59 \%$ van die lesings in die kritiese apparaat ' $n$ C- of Dwaardering het, dit wil sê in die algemene kategorie: taamlik onseker of baie onseker val (vgl statistieke versamel deur Edwards 1977: 122). Uit die ongeveer 1440 variasie-eenhede in die apparaat van $\mathrm{UBS}^{3}$ is daar dus oor bykans 900 variasie-eenhede taamlike onsekerheid. Hieruit moet nie afgelei word dat die teks in die algemeen $59 \%$ onseker is nie, aangesien die oorgrote meerderheid van die variasie detail soos spelling, punktuasie of woordorde raak. Tog is die syfer betekenisvol, aangesien die apparaat van hierdie teks só ontwerp is dat dit die variasie-eenhede insluit wat op vertaling en verklaring van die Nuwe Testament ' $n$ invloed het. Dit sou dus beweer kon word dat ten opsigte van die werklike belangrike variasie-eenhede, belangrik vir die vertaling en interpretasie van die teks, daar $60 \%$ onsekerheid bestaan - dit in ' $n$ teks wat as 'n nuwe standaardteks aanvaar word (vgl bv Junack 1978: 134; Aland 1981: 257-275). Hierdie onsekerheid maak dit nodig om na die alternatiewe wat vandag beskikbaar is, te kyk voordat 'n finale oordeel oor die toestand van hierdie tekste in besonder en die teks van die Nuwe Testament in die algemeen gevel word. 


\subsubsection{Radikale eklektiese tekste}

Verwant aan die gematigde eklektisisme, in soverre as wat dit aan dieselfde onderliggende eklektiese beginsel verbonde is, is die radikale eklektisisme. Hierdie metode verskil egter van gematigde eklektisisme daarin dat dit slegs interne getuienis gebruik om tekskritiese probleme op te los. Dit ignoreer die teksgeskiedenis, die datering en waarde van manuskripte, geheel en al. Hierdie ignorering van historiese getuienis $k a n$ in ' $n$ sekere sin aan die probleme rondom die rekonstruksie van die geskiedenis van die teks, wat uit die ontdekking van die papiri gespruit het, gewyt word. Vir hierdie tekskritici is die geskiedenis van die teks so onseker, dat dit geen getuienis vir die oplossing van variasieeenhede kan bied nie. Die metode volg gevolglik'n volledige eklektiese benadering tot die teks. (Vgl Elliott 1968: 1-11; 1972: 338-343; 1974: 338-353; 1978: 95-115; Epp 1976: 211-257; Fee 1976: 174-197; Flatt 1975: $102-114$.)

In hierdie volledige eklektiese benadering lê egter ook die swakheid van die metode, deurdat dit die eie aard en wese van die Tekskritiek ignoreer deur die dokumentêre getuienis te ignoreer en die Tekskritiek so aan hulpwetenskappe, wat tradisioneel die bronne vir die oorweging van interne getuienis is, uit te lewer. Op hierdie wyse word die eie aard en selfstandigheid van die Tekskritiek in gevaar gestel, hoewel die gebruik van hulpwetenskappe as sodanig nie 'n probleem is nie. Vandag gebruik slegs twee tekskritici, George D Kilpatrick en J Keith Elliott, hierdie metode. Kilpatrick het in die vyftigerjare begin om 'n teks aan die hand van hierdie metode saam te stel, die sogenaamde Greek-English Diglot for the use of translators (Diglot). Na die verskyning van 'n aantal boeke van die Nuwe Testament (die vier Evangelies, die Algemene Briewe, die Pastorale Briewe, Romeine en die twee Korintiërbriewe - vgl Kilpatrick 1961-64) het hy die projek laat vaar. 'n Ontleding van die teks toon dat dit redelik radikaal kan wees, omdat dit soms lesings bevat wat in slegs enkele laat minuskels gevind word (vgl Metzger 1968a: 178 vir voorbeelde). Dit lyk ook of dit iets van 'n terugkeer na die teks van die TR kan meebring.

\subsubsection{Die meerderheidsteks - GNTMT}

Naas die radikale eklektisisme bestaan daar vandag nog een belangrike metoderigting wat in werklikheid 'n ou benadering in ' $n$ nuwe kleed is. In die laat sestiger- en vroeë sewentigerjare het daar naamlik 'n nuwe beweging terug na die TR ontstaan. Zane C Hodges (vgl Hodges 1968: $334-345$; 1971: 27-35; 1978a: 143-155; 1978b: 161-164; Hodges \& 
Hodges 1980: 159-169), Wilbur N Pickering, 'n student van Hodges (vgl Pickering 1973: 216-305; 1978: 165-167; 1980) en Jakob van Bruggen (vgl Van Bruggen 1976) is vandag aan die voorpunt van pogings om die TR in ere te herstel deur 'n nuwe kritiese uitgawe van die TR daar te stel. Dit het reeds ' $n$ praktiese neerslag gevind, deurdat sowel 'n heruitgawe van die Nuwe Testament van die King James Version (KJV) as 'n nuwe Griekse teks wat op die meerderheidsteks gegrond is, The Greek New Testament according to the majority text (GNTMT) in 1982 verskyn het (Hodges \& Farstad 1982). Dit blyk dat die beweging in veral die Derde Wêreldlande in Suid-Amerika, waar die Verenigde Bybelgenootskappe minder invloed het, ' $n$ afsetgebied het (Nida 1981: 375-380).

Sonder om in besonderhede op die rigting in te gaan, is dit tog noodsaaklik om die belangrikste standpunte kortliks op te som: Die hoofelement van die rigting is dat die teks wat in die meerderheid manuskripte (daarom die meerderheidsteks) gevind word, die laatBisantynse of laat-Middeleeuse teks (die teks van die TR en die OAB), nader aan die teks van die outograwe is as enige ander teks. As bewys word onder andere daarop gewys dat

- $90 \%$ of $95 \%$ van die Griekse manuskripte wat vandag bekend is, dieselfde teks het (vgl Pickering 1980: 118-119; Hodges 1978a: 152);

- daar geen materiële bewys in die vorm van vroeë manuskripte van die ouderdom van die meerderheidsteks is nie, omdat die goeie manuskripte (wat aan die meerderheidsteks verwant is) so baie gebruik is dat hulle verweer het, met die gevolg dat die vroeë manuskripte wat vandag beskikbaar is, oorblyfsels is van 'n teks wat deur die algemene gebruikers verwerp is (vgl Pickering, 1980: 129-134; Hodges 1978a: 153; Van Bruggen 1976: 24-25);

- die papiri bewys het dat die Bisantynse teks voor die 4 de eeu bestaan het, omdat daar sekere lesings in die papiri voorkom wat voorheen as tipies-Bisantynse lesings bestempel is (vgl Pickering 1980: 60; Hodges 1968: 344-345; veral Sturz 1984, wat 'n hele studie aan die saak gewy het);

- die aanvaarding van die teks van die Nuwe Testament as gesagvol tot 'n noukeurige oorlewering daarvan gelei het, omdat die vroeë gebruikers van die teks konserwatief was en ontsag vir die teks gehad het (Pickering 1980: 99-115);

- die meeste van die outograwe waarskynlik in Antiochië bewaar is, met die gevolg dat die teks in hierdie gebied waarskynlik meer 
betroubaar is as selfs vroeër manuskripte elders, omdat die kerke in hierdie gebied hul manuskripte telkens met die outograwe self kon vergelyk (vgl Van Bruggen 1976: 22);

- dit statisties nie moontlik is dat die teks wat in die meerderheid manuskripte gevind word, 'n ander oorsprong kan hê as die outograwe nie (vgl Hodges \& Hodges 1980: 159-169).

Hierdie is enkele van die belangrikste argumente wat aangevoer word om die primaat van die meerderheidstek te bewys. Die swakhede in die argumente spreek in baie gevalle vanself en dit is nie nodig om hulle hier te bespreek nie. In elk geval is die probleme in hierdie argumente reeds herhaaldelik en oortuigend deur kritici van hierdie metoderigting uitgewys (vgl Fee 1978a: 157-160; 1978b: 19-33; 1978/79: 397-423; 1980: 107-118; Taylor 1977: 377-381; 1978: 169-177). Agter hierdie argumente sit daar egter ' $n$ belangrike uitgangspunt en 'n kort aantekening hieroor is noodsaaklik.

As uitgangspunt van hierdie beweging word naamlik beweer dat die Nuwe Testament anders as ander dokumente is, in die sin dat dit die geïnspireerde Woord van God bevat. Hieruit word afgelei dat ook die teks daarvan op ' $n$ ander wyse as die teks van sekulêre dokumente in die herstelproses benader moet word en dat dit nie (soos Westcott en Hort eksplisiet beweer het) aan die hand van gewone tekskritiese metodes herstel kan word nie. In die herstel van die teks moet naamlik rekening gehou word met die beloftes in die Bybel dat die Woord nooit sal vergaan nie. Dit word geïnterpreteer as beloftes dat die teks van die Nuwe Testament bewaar sal word en nooit verlore sal gaan nie. Die 'bewaarde teks' word dan by die teks wat algemeen in die (Griekse) kerke gebruik is, gesoek, met die gevolg dat die meerderheidsteks, of die teks wat algemeen in die middeleeue gebruik is, as die bewaarde teks geïdentifiseer word. (Vgl bv Hodges 1971: 29; Van Bruggen 1976: 40; Pickering 1980: 153.) Omdat hierdie bewerings egter nie op wetenskaplike wyse gemotiveer kan word nie, word allerlei argumente soos hierbo aangehaal, geopper om hierdie uitgangspunt 'wetenskaplik' te motiveer, om gevolglik die bestaande wetenskaplike rigtings verdag te maak as synde 'skrifkrities', of om die bestaande konklusies ten opsigte van die waarde van die oudste manuskripte as irrelevant aan te toon. Die uiteinde van die saak is dat in die mees radikale vorm van hierdie rigting daar vir ' $n$ soort 'Bybelse metode' of dalk geloofsgefundeerde metode gepleit word. Dit is waarskynlik wat ten grondslag van Van Bruggen (1976: 40) se pleidooi, in aansluiting by EF Hills se onderskeid 
tussen rasionalistiese en Christelike metodes (vgl Hills 1956: 19) vir 'n 'reformatorische textkritiek'. Wie egter die moeite doen om die uitgangspunt te ontleed, kom gou agter dat dit doodeenvoudig op swak eksegese berus en dat die konsekwensies daarvan selfvernietigend is, soos deur talle kritici van hierdie rigting duidelik aangetoon is.

In werklikheid is hierdie rigting niks anders as 'n terugkeer na die TR nie. Hoewel Hodges ' $n$ metode ontwerp om 'n kritiese uitgawe van die meerderheidsteks saam te stel (vgl Hodges \& Farstad 1982: xi-xii), wat in die GNTMT neerslag vind, kon hy dit om bepaalde redes slegs op die teks van Openbaring en die perikoop van die owerspelige vrou (Joh 7: 11-8: 53) toepas. Vir die res van die teks is hy tevrede om bloot manuskripte te tel en telkens die lesing wat in die numeriese meerderheid manuskripte voorkom, by die teks in te sluit. So word sy teks dus 'n meerderheidsteks in die letterlike sin van die woord. Daardeur word een van die mees fundamentele beginsels in die Tekskritiek, dat manuskripte geweeg en nie getel moet word nie, vermy, sonder dat dit enigsins metodologies beredeneer word waarom die betrokke beginsel nie geldig is nie. Desnieteenstaande word die teks aangebied en gebruik as ' $n$ beter en meer betroubare weergawe van die outograwe as enige ander bestaande teks en is die teks wat die naaste aan hierdie teks vir sy ondersteuners kom, die TR, ondanks die bewese swakhede en probleme van die TR.

Op grond van hierdie getuienis kan kritici van die meerderheidsteks en die metodes wat gebruik word om dit saam te stel, nie kwalik geneem word as hulle in hierdie rigting niks anders as ' $n$ verskansde en bevooroordeelde poging van die fundamentalisme om die TR in ere te herstel, sien nie. 'n Metode wat bereid is om meer as twee eeue se metodologiese ontwikkelinge in die Nuwe-Testamentiese Tekskritiek te ignoreer ten gunste van 'n ou, uitgediende en onbetroubare teks, sonder om 'n behoorlike wetenskaplik-gemotiveerde metodologiese alternatief te bied, kan nie verwag om in 'n krities-wetenskaplike wêreld waarin metodologiese verantwoording ' $n$ al groter rol speel, aanvaar te word of selfs ernstig beskou te word nie. Wanneer dit egter teen die agtergrond van die uitgangspunt daarvan beoordeel word, is dit duidelik wat die bron van die rigting is en is dit duidelik dat die hele saak subjektief, ongebalanseerd en bevooroordeeld is - 'n poging om te midde van 'n onsekere wetenskaplike wêreld (in tekskritiese sin) vaste en absolute teologiese antwoorde vir (teks)historiese probleme te soek.

Juis die bevooroordeelde karakter van die metode maak dit onweten- 
skaplik, onmetodologies en selfs ontekskrities. Dit is nie in staat om die toets van wetenskaplikheid te deurstaan nie en daarom kan dit nie in 'n wetenskaplike konteks ernstig as 'n alternatief vir die gematigde eklektiese metodes oorweeg word nie, nie eers in dieselfde mate as wat die radikale eklektiese metodes as alternatief oorweeg kan word nie. Die resultate daarvan is nog meer onseker as dié van die gematigde eklektiese metodes - trouens dit staan vandag vas dat die resultate van hierdie metode nié die teks van die outograwe verteenwoordig nié. Op sigself is die blote bestaan en toenemende populariteit van hierdie rigting egter ' $n$ bewys van die krisis waarin Nuwe-Testamentiese Tekskritiek gedompel is (vgl Epp 1974: 105).

\section{GEVOLGTREKKING: DIE BETROUBAARHEID VAN DIE TEKS}

Die grootste enkele kenmerk van die huidige situasie in die NuweTestamentiese Tekskritiek is 'n onsekerheid en terughoudendheid ten opsigte van die rigting waarin die metodiek van hierdie wetenskap moet ontwikkel (vgl Epp 1974: 387-405; 1976: 242; 1980: 131-151). Waaroor daar min of meer konsensus onder tekskritici bestaan, is dat ouer modelle, sowel ten opsigte van die rekonstruksie van die teksgeskiedenis as ten opsigte van die metode vir die herstel van die teks, wat vroeër 'n groot mate van sekerheid ten opsigte van die teks gewaarborg het, nie meer in alle besonderhede geldig is nie en gevolglik nie meer dieselfde mate van sekerheid kan waarborg nie. Daar is konsensus dat die modelle hersien moet word. Presies hoe hierdie hersiening gedoen moet word, watter aspekte van die metodiek dit raak en wat die omvang daarvan moet wees, is belangrike vrae wat nog nie ten volle beantwoord is nie en wat die metodologiese krisis in die NuweTestamentiese Tekskritiek duidelik vergestalt.

Dit het uiteraard belangrike konsekwensies vir die toestand van die teks of tekste wat vandag algemeen gebruik word, sodat die probleme ook in hierdie tekste vergestalt word. Dit blyk dat daar in breë trekke taamlike konsensus is dat die tipe teks wat in $\mathrm{UBS}^{3}$ en $\mathrm{NA}^{26}$ gevind word, 'n goeie algemene verteenwoordiger van die outograwe is, met ander woorde dat die algemene karakter van hierdie tekste, synde byvoorbeeld kort tekste, waarin talle woorde, frases, uitdrukkings, verse en selfs langer gedeeltes wat in ander tekste soos die TR voorkom, ontbreek, dié van die outograwe goed weerspieël. Waaroor egter onsekerheid bestaan, is presies watter tradisioneel bekende lesings in 
werklikheid nie outentiek is nie. Dat die teks basies kort is, is seker; presies hoe kort dit is, is egter onseker. Hierdie onsekerheid ten opsigte van die detail kom in $\mathrm{UBS}^{3}$ en $\mathrm{NA}^{26}$ duidelik na vore, deurdat tekste soos die bloedsweet in Getsemane (Luk 22: 43-44), die vertelling van die owerspelige vrou (Joh 7: 53-8: 11) of die lang slot van Markus (Mark 16: 9-22) in die teks opgeneem word, terwyl daar by die samestellers klaarblyklik konsensus bestaan het dat die betrokke gedeeltes nie outentiek is nie (vgl Metzger 1971: 122-126; 177; 219-222 oor hierdie drie gedeeltes). In hierdie verband is $\mathrm{UBS}^{2}$ (Aland et al 1968), wat hierdie en ander dele soos die lang lesing in die Nagmaalberig in Lukas (Luk 22: 19b-20) weglaat, ' $n$ beter teks, omdat dit meer konsekwent volgens die oortuigings van die samestellers saamgestel is. Die hantering van die saak in $\mathrm{UBS}^{3}$ en $\mathrm{NA}^{26}$ dra tot die algemene onsekerheid ten opsigte van die detail in die teks by, deurdat verwarrende kriteria by die keuse van die outentieke lesing gebruik word. So 'n hantering van die saak dien slegs daartoe dat van hierdie lesings steeds, onder andere deurdat dit in moderne vertalings voorkom, onder die gebruikers van die teks geyk is, hoewel daaroor 'n redelike mate van konsensus bestaan dat hulle nie outentiek is nie. Daar word met afwagting gekyk na wat die 4de uitgawe van die UBS-reeks, wat skynbaar binne die volgende vier of vyf jaar gaan verskyn, gaan oplewer. Hopelik sal probleme soos wat hierbo ten opsigte van $\mathrm{UBS}^{3}$ genoem is, gekorrigeer word.

Die toestand van $\mathrm{UBS}^{3}$ en $\mathrm{NA}^{\mathbf{2 6}}$, sowel die mate van sekerheid wat dit bied as die oorblywende onsekerheid, het natuurlik belangrike gevolge vir ander aspekte van die Nuwe-Testamentiese wetenskap, soos die verklaring en vertaling van die Nuwe Testament. Daar kan nie langer voortgegaan word om die konsekwensies van die moderne kritiese teks en die onsekerheid rondom hierdie teks te ignoreer nie. Op grond van betroubaarheid ten opsigte van die algemene karakter van die teks sal dit vir die doel van verklaring en preke, byvoorbeeld, aanvaar moet word

- dat Jesus nie in die tuin van Getsemane bloed gesweet het nie (Luk 22: 43-44);

- dat daar slegs ses kruiswoorde uitgepreek is en dat die sogenaamde eerste kruiswoord nie in Lukas se oorspronklike geskrif verhaal is nie (Luk 23: 34);

- dat die water by die bad van Betesda nie deur 'n engel geroer is nie (Joh 5: 3-4); 
- dat Johannes nooit die vertelling van Jesus se gesprek met die owerspelige vrou opgeteken het nie (Joh 7: 53-8: 11);

- dat die Evangelie volgens Markus nie 'n slot het nie (Mark 16: 9-20);

- dat Lukas se Evangelie 'n drasties verkorte weergawe van die 'Ons Vader' bevat (Luk 11: 2-4);

- dat die 'Ons Vader' nooit met 'n doksologie afgesluit is nie (Matt 6: 13);

- dat Filippus nooit vir die hofdienaar van Ethiopië gevra het of hy glo voordat hy hom gedoop het nie (Hand 8: 37);

- moontlik selfs dat Romeine nie 'n sestiende hoofstuk gehad het nie en nie met ' $n$ doksologie afgesluit is nie (Rom 16: 25-27).

Dit sal aan kerklidmate verduidelik moet word dat die vertalers van die nuwe Afrikaanse Bybel nie die Naam van Jesus, die drie-eenheid van God of die godheid van Christus 'wegvertaal' het nie, maar dat hulle in ooreenstemming met ontwikkelinge in die Nuwe-Testamentiese Tekskritiek 'n teks gebruik het

- waarvolgens daar nooit na 'drie hemelse getuies' in die eerste brief van Johannes verwys was nie (1 Joh 5: 7-8);

- waarvolgens Markus die Evangelie van Jesus Christus en nie die Evangelie van Jesus Christus, die Seun van God nie, beskryf (Mark 1: 1);

- dat in die eerste Korintiërbrief slegs na die dag van die Here en nie die dag van die Here Jesus of die dag van die Here Jesus Christus verwys nie (1 Kor 5: 5).

Ook die formuliere en belydenisskrifte sal in die lig van die gebruik van die kritiese teks voortdurend soos die teks verander, hersien moet word en daar sal byvoorbeeld besin moet word

- of die verwysing na die bloedsweet in Getsemane (Luk 22: 43-44) steeds in die Nagmaalsformulier behou kan word; en

- of vraag 128 en 129 en die verwysing na die doksologie aan die einde van die 'Ons Vader' (Matt 6: 13) nie dalk uit Sondag 52 van die Heidelbergse Kategismus verwyder moet word nie.

Hierdie is maar enkele voorbeelde van die konsekwensies van 'n krities-wetenskaplike benadering tot die teks van die Griekse Nuwe 
Testament, wat nie meer geïgnoreer kan word nie. Hoewel daar oor sommige van hierdie voorbeelde onsekerheid bestaan, kan dit nie langer bekostig word dat die praktiese hantering van die teks met dit wat in teorie aanvaar word, bots nie. Daar kan nie voortgegaan word om in die praktiese gebruik van die Nuwe Testament steeds die TR te gebruik, terwyl in teorie aanvaar en erken word dat dit 'n onbetroubare en swak teks is nie. Dit is belangrik dat die konsekwensies van die gebruik van nuwe tekste aanvaar word en dat die prediking, verklaring en kerklike dokumente op die nuutste en beste beskikbare tekste gebaseer word, selfs al beteken dit dat die genoemde dokumente gereeld in die lig van nuwere ontwikkelinge in die Nuwe-Testamentiese Tekskritiek hersien moet word en gevolglik gereeld verander moet word. Dit lyk of die dinamiese element wat in die samestelling van die teks met die aanvaarding van die kritiese metode en teks in 1881 na vore getree het, ook 'n dinamiese benadering tot die gebruik van die teks noodsaak, waarvoor 'n bepaalde openheid by die gebruikers van die teks nodig is.

Die huidige toedrag van sake noop die gebruikers van die Nuwe Testament om 'n meer 'oop' of 'los' houding teenoor die teks in te neem. Dit lyk onwaarskynlik dat 'n teks met groter sekerheid ten opsigte van die detail in die afsienbare toekoms saamgestel kan word, aangesien daar nog nie weer belangrike manuskripte uit die tydperk voor die $4 \mathrm{de}$ eeu aan die lig gekom het nie. Sonder sulke manuskripte is die akkurate en betroubare rekonstruksie van die geskiedenis van die teks, die keuse van 'n beste manuskrip en gevolglik ook die samestelling van ' $n$ meer betroubare teks ' $n$ feitlik onbegonne taak. Gevolglik lyk dit of die gebruiker van die teks aan 'n teks gewoond sal moet raak waarvan die lesings nie in absolute sin vasstaan nie, maar waarin, volgens nuwe getuienis wat na vore kom, hetsy in die vorm van manuskripte, hetsy in die vorm van ontwikkelinge in die metodiek, verander sal word en waarin ten opsigte van die betroubaarheid van indiwiduele lesings gedifferensieer sal word. Dit lyk ò 'n nuwe beskouing van die teks aanvaar sal moet word ò geleer sal moet word om aan die teks van die Nuwe Testament te dink as 'n lewende entiteit wat voortdurend kan verander, eerder as om daaraan te dink as iets permanents wat vir eens en vir altyd herstel is en gevolglik dieselfde moet bly. Presies wat die konsekwensies hiervan op die lange duur vir die teologie en verklaringswetenskappe sal wees, is moeilik om te bepaal. Die tyd sal daarop 'n antwoord moet gee. 


\section{Literatuurverwysings}

ALAND, K 1957a. Papyrus Bodmer II. Ein erster Bericht. TLZ 82, 161-184.

ALAND, K 1957b. Das NT auf Papyrus: Zur Entdeckung der ältesten Handschriften. Universitas 12, 585-590.

ALAND, K 1959. The present position of New Testament textual criticism, in Aland, $\mathrm{K}$ et al (Hrsgs), Studia Evangelica, 1. Teil, 717-731. Berlin: Akademie.

ALAND, K 1965. The significance of the papyri for progress in New Testament research, in Hyatt, JP (ed), The Bible in modern scholarship, 325-346. New York: Abingdon.

ALAND, K 1967. Die Konsequenzen der neueren Handschriftenfunde für die neutestamentliche Textkritik. NT 9, 81-106.

ALAND, K 1970/71. Bemerkungen zu den gegenwärtigen Möglichkeiten textkritischen Arbeit aus Anlass einer Untersuchung zum Cäsarea-Text der Katholischen Briefe. NTS $17,1-9$

ALAND, K 1979. The twentieth-century interlude in New Testament textual criticism, in Best, E \& Wilson, $\mathrm{R}$ (eds), Text and interpretation: Studies in the New Testament presented to Matthew Black, 1-14. Cambridge: Cambridge University Press.

ALAND, K 1981. Der neue 'Standard-Text' in seinem Verhältnis zu den frühen Papyri und Majuskeln, in Epp, EJ \& Fee, GD (eds), New Testament textual criticism: Its significance for exegesis. Essays in honour of Bruce M Metzger, 257-275. Oxford: Clarendon.

ALAND, K 1982. Der Textcharakter der frühen Papyri und Majuskeln, in Bericht der Hermann Kunst-Stiftung zur forderung der neutestamentlichen Textforschung für die Jahre 1979 bis 1981, 43-59.

ALAND, K \& ALAND, B 1982. Der Text des Neuen Testaments: Einführung in die wissenschaftlichen Ausgaben sowie in Theorie und Praxis der modernen Textkritik. Stuttgart: Deutsche Bibelgesellschaft.

ALAND, K, BLACK, M, METZGER, BM \& WIKGREN, AP (eds) 1966. The Greek New Testament. 1st ed. London: United Bible Societies.

ALAND, K, BLACK, M, MARTINI, CM, METZGER, BM \& WIKGREN, AP (eds) 1968. The Greek New Testament. 2nd ed. London: United Bible Societies.

ALAND, K, BLACK, M, MARTINI, CM, METZGER, BM \& WIKGREN, AP (eds) 1975. The Greek New Testament. 3rd ed. London: United Bible Societies.

ALAND, K, BLACK, M, MARTINI, CM, METZGER, BM \& WIKGREN, AP (eds) 1979. Novum Testamentum Graece. 26th ed. Stuttgart: Deutsche Bibelstiftung.

ALAND, K, BLACK, M, MARTINI, CM, METZGER, BM \& WIKGREN, AP (eds) 1983. The Greek New Testament. 3rd cor ed. London: United Bible Societies.

BENTLEY, JH 1976. Erasmus' Annotationes in Novum Testamentum and the textual criticism of the Gospels. Achive for Reformation History 67, 33-53.

BIRDSALL, JN 1960. The Bodmer Papyrus of the Gospel of John. London: Tyndale.

BLACK, M. 1977. The United Bible Societies' Greek New Testament evaluated: A reply. BT 28, 116-120.

BRISTOL, LO 1950. New Testament textual criticism in the 18th century. JBL 69, 101-112. BURGON, JW 1883. The revision revised. London: John Murray.

BURGON, JW 1896a. The traditional text of the Holy Gospels vindicated and established. Arranged, completed and edited by Edward Millar. London: Bell.

BURGON, JW 1896b. The causes of the corruption of the traditional text of the Holy Gospels. Arranged, completed and edited by E Millar. London: Bell.

CLARK, KW 1959. Observations on the Erasmian notes in codex 2, in Aland, $\mathrm{K}$ et al (Hrsgs), Studia Evangelica, 1. Teil, 749-756. Berlin: Akademie.

CLARK, KW 1962. The text of the Gospel of John in third-century Egypt. NT 5, 17-24.

CLARK, KW 1968. Today's problems with the critical text of the New Testament, in Rylaarsdam, JC (ed), Transitions in biblical scholarship. 157-169. Chicago: University of Chicago Press. 
COLWELL, EC 1969. Studies in methodology in textual criticism of the New Testament. Leiden: Brill. (New Testament Tools and Studies 9.)

DE JONGE, HJ 1971. Daniel Heinsius and the Textus Receptus of the New Testament. Leiden: Brill.

DE JONGE, HJ 1980. Erasmus and the comma johanneum. ETL 56, 381-389.

DE JONGE, HJ 1984. Novum Testamentum a nobis versum: The essence of Erasmus' edition of the New Testament. JBL 35, 394-413.

DELOBEL, J 1977. The Bodmer Papyri of John: A short survey of the methodological problems. BETL 66, 317-323.

EDWARDS, EJ 1977. On using the textual apparatus of the UBS Greek New Testament. BT $28,121-142$.

ELLIOTT, JK 1968. The Greek text of the Epistles to Timothy and Titus. Salt Lake City: University of Utah. (Studies and Documents 36.)

ELLIOTT, JK 1972. Rational criticism and the text of the New Testament. Theology 75, 338-343.

ELLIOTT, JK 1974. Can we recover the original New Testament? Theology 77, 338-353.

ELLIOTT, JK 1978. In defence of thoroughgoing eclecticism in New Testament textual criticism. RQ 21, 95-115.

EPP, EJ 1974. The 20th century interlude in New Testament textual criticism. JBL 93, 386-414.

EPP, EJ 1976. The eclectic method in New Testament textual criticism: Solution or symptom? HTR 69, 211-257.

EPP, EJ 1980. A continuing interlude in New Testament textual criticism? HTR 73, $131-151$.

FEE, GD 1968. Papyrus Bodmer II (Pos): Its textual relationship and scribal characteristics. Salt Lake City: University of Utah. (Studies and Documents 34.)

FEE, GD 1971. The text of John in Origen and Cyril of Alexandria. A contribution to methodology in the recovery and analysis of patristic citations. Bib 52, 357-394.

FEE, GD 1976. Rigorous or reasoned eclecticism - which? in Elliott, JK (ed), Studies in the New Testament Language and text: Essays in honour of George D Kilpatrick on the occasion of his sixty-fifth birthday, 174-197. Leiden: Brill.

FEE, GD 1978a. Modern textual criticism and the majority text: A rejoinder. JETS 21, $157-160$.

FEE, GD 1978b. Modern textual criticism and the revival of the Textus Receptus. JETS 21, 19-33.

FEE, GD 1978/79. A critique of WN Pickering's The identity of the New Testament text: A review article. WTJ $41,397-423$.

FEE, GD 1980. The majority text and the original text of the New Testament. BT 31, $107-118$.

FILSON, FV 1957. A new papyrus manuscript of the Gospel of John. BA 20, 54-63.

FINEGAN, J 1974. Encountering New Testament manuscripts: A working introduction to textual criticism. Grand Rapids: Eerdmans.

FLATT, D 1975. Thoroughgoing eclecticism as a method of textual criticism. $R Q 18$, $102-114$

HILLS, EF 1956. The King James version defended. Des Moines: Christian Research.

HODGES, ZC 1968. The Greek text of the King James version. BS 125, 334-345.

HODGES, ZC 1971. Rationalism and contemporary New Testament textual criticism. BS $128,27-35$.

HODGES, ZC 1978a. Modern textual criticism and the majority text: A response. JETS 21, $143-155$.

HODGES, ZC 1978b. Modern textual criticism and the majority text: A surrejoinder. JETS $21,161-164$ 
HODGES, ZC \& FARSTAD, AL (eds) 1982. The Greek New Testament according to the majority text. Nashville: Thomas Nelson.

HODGES, ZC \& HODGES, DM 1980. The implications of statistical probability for the history of the text, in Pickering, WN, The identity of the New Testament text. 2nd ed, 159-169. Nashville: Thomas Nelson.

HOSKIER, HC 1914. Codex B and its allies: $A$ study and indictment, 2 Vols. London: Quaritch.

JORDAAN, GJC 1975. Die bronne waaruit die Nuwe Testament van die Afrikaanse Bybel vertaal is - 'n filologiese studie. M A-verhandeling. Potchefstroom: Potchefstroomse Universiteit vir Christelike Hoër Onderwys.

JUNACK, K 1978. The reliability of the New Testament text from the perspective of textual criticism. BT 29, 128-140.

KILPATRICK, GD (ed) 1961-64. A Greek-English Diglot for the use of translators. London: British and Foreign Bible Societies.

KING, MA 1964. Notes on the Bodmer manuscript. BS 121, 54-57.

KLIJN, AF] 1956/57. Papyrus Bodmer II (John 1-14) and the text of Egypt. NTS 3, 327-334.

KLIJN, AF] 1960/61. De stand van het onderzoek naar de geschiedenis van de tekst van het Nieuwe Testament. NTT 15, 161-168.

KLIJN, AFJ 1971. Recente ontwikkelingen op het terrein van de N T Tekstkritiek. Rondom het Woord 13, 249-254.

LAKE, K 1928. The text of the New Testament. 6th rev ed. London: Rivington.

LAKE, K, BLAKE, RP \& NEW, S 1928. The Caesarean text of the Gospel of Mark. HTR 21, 207-404.

LAKE, K \& LAKE, S 1941. Family 13 (the Ferrar group). The text according to Mark: With a collation of codex 28 of the Gospels. Philadelphia: University of Pennsylvania. (Studies and Documents 11.)

MARTINI, CM 1978. Is there a late-Alexandrian text of the Gospels? NTS 24, 285-296.

METZGER, BM 1961/62. The Bodmer papyrus of John. ET 73, 201-203.

METZGER, BM 1963. Chapters in the history of New Testament textual criticism. Grand Rapids: Eerdmans.

METZGER, BM 1966/67. Second thoughts XII: The textual criticism of the New Testament, pt 2. ET 78, 372-375

METZGER, BM 1968a. The text of the New Testament: Its transmission, corruption and restoration. 2nd ed. New York: Oxford.

METZGER, BM 1968b. Historical and literary studies - pagan, Jewish and Christian. Leiden: Brill. (New Testament Tools and Studies 7.)

METZGER, BM 1971. A textual commentary on the Greek New Testament. United Bible Societies.

METZGER, BM 1975. The practice of textual criticism among the church fathers, in Livingstone, EA (ed), Studia Patristica XII, pt 1, 340-349. Berlin: Akademie.

METZGER, BM 1980. New Testament studies - philological, versional and patristic. Leiden: Brill. (New Testament Tools and Studies 10.)

NIDA, EA 1981. The New Testament Greek text in the third world, in Epp, EJ \& Fee, GD (eds), New Testament textual criticism: Its significance for exegesis. Essays in honour of Bruce M Metzger, 375-380. Oxford: Clarendon.

PETZER, JH 1985. Die grondteks vir die vertaling van die Nuwe Testament in die Afrikaanse Bybel. Literator 6, 73-87.

PICKERING, WN 1973. The contribution of William Burgon to New Testament textual criticism, in Fuller, DO (ed), True or False? The Westcott-Hort textual theory examined, 216-305. Grand Rapids: Grand Rapids International Publications.

PICKERING, WN 1978. 'Queen Anne ...' and all that: A response. JETS 21, 165-167.

PICKERING, WN 1980. The identity of the New Testament text. 2nd ed. Nashville: Thomas Nelson. 
PORTER, CL 1967. An analysis of the textual variation between pap 75 and the codex Vaticanus in the text of John, in Daniels, BL \& Suggs, MJ (eds), Studies in the history and text of the New Testament in honor of Kenneth Willis Clark, 71-80. Salt Lake City: University of Utah. (Studies and Documents 29.)

REICKE, B 1966. Erasmus und die neutestamentliche Textgeschichte. TZ 22, 254-265.

SCRIVENER, FHA 1894. A plain introduction to the criticism of the New Testament, 2 Vols. 4th ed. London: Bell.

SOUTER, A 1960. Text and canon of the New Testament, rev by CSC Williams. 2nd ed. London: Duckworth.

STURZ, HA 1984. The Byzantine text-type and New Testament textual criticism. Nashville: Thomas Nelson.

TARELLI, CC 1943. Erasmus' manuscripts of the Gospels. ITS 44, 155-162.

TAYLOR, RA 1977. Queen Anne resurrected? A review article. JETS 20, 377-381.

TAYLOR, RA 1978. 'Queen Anne' revisited: A rejoinder. JETS 21, 169-171.

TURNER, CH 1924. Marcan usage: Notes, critical and exegetical, on the Second Gospel, 1. JTS 25, 377-386.

TURNER, CH 1925. Marcan usage: Notes, critical and exegetical, on the Second Gospel, 2. ITS 26, 12-20.

TURNER, CH 1927. A textual commentary on Mk 1. JTS 28, 145-158.

VAGANEY, L 1937. An introduction to the textual criticism of the New Testament. Transl by BV Miller. London: Sands.

VAN BRUGGEN, J 1976. De tekst van het Nieuwe Testament. Rede gehouden bij de overdracht van het rectoraat der Theologische Hogeschool van de Gereformeerde Kerken in Nederland op 8 december 1975. Groningen: De Vuurbaak. (Kampen Bijdragen 16.)

WESTCOTT, BF \& HORT, FJA 1974. The New Testament in the original Greek: Introduction and appendix. New York: Harper. (1st edition 1881.)

ZUNTZ, G 1953. The text of the Epistles: A disquisition upon the corpus paulinum. London: Oxford University Press. 